\title{
The Potential for Natural Stones from Northeastern Brazil to Be Used in Civil Construction
}

\author{
Fabiana Pereira da Costa ${ }^{1}$ (D), Jucielle Veras Fernandes ${ }^{1} \mathbb{D}$, Luiz Ronaldo Lisboa de Melo ${ }^{1}$, \\ Alisson Mendes Rodrigues ${ }^{1,2, *(D)}$, Romualdo Rodrigues Menezes ${ }^{1,2}\left(\mathbb{D}\right.$ and Gelmires de Araújo Neves ${ }^{1,2}(\mathbb{D}$ \\ 1 Postgraduate Program in Materials Science and Engineering (PPG-CEMat), Materials Engineering \\ Department, Federal University of Campina Grande, Av. Aprígio Veloso - 882, Bodocongó, \\ Campina Grande, PB 58 429-900, Brazil; fabiana.costa@estudante.ufcg.edu.br (F.P.d.C.); \\ jucielle_fernandes@hotmail.com (J.V.F.); lisboa@ifce.edu.br (L.R.L.d.M.); \\ romualdo.menezes@ufcg.edu.br (R.R.M.); gelmires.neves@ufcg.edu.br (G.d.A.N.) \\ 2 Academic Unit of Materials Engineering, Science and Technology Center, Federal University of Campina \\ Grande, Av. Aprígio Veloso - 882, Bodocongó, Campina Grande, PB 58 429-900, Brazil \\ * Correspondence: alisson.mendes@professor.ufcg.edu.br
}

Citation: Costa, F.P.d.; Fernandes, J.V.; Melo, L.R.L.d.; Rodrigues, A.M.; Menezes, R.R.; Neves, G.d.A. The Potential for Natural Stones from Northeastern Brazil to Be Used in Civil Construction. Minerals 2021, 11 440. https://doi.org/10.3390/ $\min 11050440$

Academic Editor: Donatella Barca

Received: 16 March 2021

Accepted: 30 March 2021

Published: 21 April 2021

Publisher's Note: MDPI stays neutral with regard to jurisdictional claims in published maps and institutional affiliations.

Copyright: (c) 2021 by the authors. Licensee MDPI, Basel, Switzerland. This article is an open access article distributed under the terms and conditions of the Creative Commons Attribution (CC BY) license (https:// creativecommons.org/licenses/by/ $4.0 /)$.

\begin{abstract}
Natural stones (limestones, granites, and marble) from mines located in northeastern Brazil were investigated to discover their potential for use in civil construction. The natural stones were characterized by chemical analysis, X-ray diffraction, differential thermal analysis, and optical microscopy. The physical-mechanical properties (apparent density, porosity, water absorption, compressive and flexural strength, impact, and abrasion) and chemical resistance properties were also evaluated. The results of the physical-mechanical analysis indicated that the natural stones investigated have the potential to be used in different environments (interior, exterior), taking into account factors such as people's circulation and exposure to chemical agents.
\end{abstract}

Keywords: natural stones; limestone; granite; marble; microstructure; characterization; physicalmechanical properties

\section{Introduction}

Since ancient times, natural stones have been used as natural stone tiles, structural pieces in architectural works, and monuments. Natural rocks play an important role in the maintenance and repair of monuments and historic buildings with national or World Heritage significance [1,2]. It is estimated that, since 2013, the world natural stones industry has grown at a rate of approximately $4.0 \%$ per year [3,4]. Brazil stands out in the mining and commercializing of natural stones, reaching fourth position worldwide, and is responsible for $7 \%$ of the sector's production [5-7]. In Brazil, the mining of natural stones in the northeast region produces 1.63 million tons per year, representing about $20 \%$ of the national production; most mining occurs in the states of Bahia and Ceará [3].

Among Brazilian natural stones, those that stand out are marble, limestone, sandstone, quartzite, slate, gneiss, and granite; these are used extensively in civil construction. These natural stones can be used as dimensional stones, tiles, kitchen countertops, and internal flooring. The enormous interest in using these stones in the civil construction sector is due to their aesthetic properties, durability, and physical and mechanical characteristics $[8,9]$. However, these stones may show gradual and slow degradation under natural conditions.

Acidic waters, environments with polluted air, and contact with chemical components can cause physical changes and modify the surface roughness, leading to granular disintegration and increased porosity $[10,11]$. Consequently, this affects mechanical behavior and some aesthetic properties, such as color or polished finish $[12,13]$. Thus, the study of the physical-mechanical, chemical and microstructural properties of these materials is essential 
for classification as to their use and for establishing the suitability of their application areas, avoiding inappropriate uses and minimizing possible failures due to misuse.

Several works have been published studying the properties and conditions of natural stones [14-16] and their mechanical behavior or durability [17-20]. Vázquez et al. [21] studied the parameters and properties of cracks in ornamental granites from Spain. Among the main conclusions, the authors found that the mineralogical composition, texture, and pore characteristics were the main factors observed in the assessment of the intensity of physical and chemical damage to stones. Saba et al. [22] evaluated the petrography of a limestone cultural heritage site in Cartagena de Indias to establish information about the mechanical properties of the monuments and uncertainties regarding replacing the pieces. The study of Brazilian ornamental stones has deepened through several research studies over the years [23-27]. Castro et al. [28,29] studied the characteristics and durability issues of Facoidal gneiss, the most significant natural and heritage stone of Rio de Janeiro (Brazil), aiming to better know its decay processes and responses to conservation practices.

Although many studies address characterizations and applications of natural stones with the potential for civil construction [30,31], knowledge of the physical-mechanical and chemical properties of natural stones in northeastern Brazil, especially limestone, has been little investigated. Thus, there is no full technical and scientific knowledge of the suitability of these materials for civil construction applications. Therefore, this research aims to investigate the physical-mechanical, microstructural, and chemical resistance properties of limestones, granites, and marbles mined in northeastern Brazil to evaluate their behavior as natural stone tiles. The natural stones were subjected to analyses regarding mineralogical and microstructural characterizations, physical-mechanical properties (water absorption, apparent density, porosity, and compressive, flexural, and impact strengths), and chemical attack resistance.

\section{Materials and Methods}

\subsection{Materials}

The natural stones used in this study are from mines located in Ceará state (Brazil) and were provided by companies. Table 1 summarizes the stone type, commercial name, identification used in this work, location of extraction, and supplier companies. The blocks of limestone, granite, and marble, approximately $300 \mathrm{~mm} \times 300 \mathrm{~mm} \times 300 \mathrm{~mm}$, were received without failures, cracks, or alteration zones. Due to their lamellar characteristics, the limestone blocks from the Cariri region (LCC and LCA) presented an average thickness of $80 \mathrm{~mm}$. The samples were cut with a diamond saw blade, and the surface was polished in an automatic polishing machine at a speed of $400 \mathrm{rpm}$. Abrasive stones of silicon carbide (numbers 400 and 600) were employed.

Table 1. The commercial name, nomenclature used in this work, type of natural stone, location of extraction, and supplier company.

\begin{tabular}{ccccc}
\hline Commercial Name & Nomenclature & Stone Types & City & Company \\
\hline Pedra Cariri Creme & LCC & Limestone & Nova Olinda & Limestone Ceará \\
Pedra Cariri Azul & LCA & Limestone & Santana do Cariri & Limestone Ceará \\
Crema Buzius & LCB & Limestone & Limoeiro do Norte & Granus S/A \\
Mont Charmont & LMC & Limestone & Limoeiro do Norte & Granus S/A \\
Bege Capri & LBC & Limestone & Limoeiro do Norte & Mont Granitos S/A \\
Blue Marine & LBM & Limestone & Limoeiro do Norte & Mont Granitos S/A \\
Bege San Marino & LBSM & Limestone & Limoeiro do Norte & Mont Granitos S/A \\
Branco Ceará & GBC & Granite & Santa Quitéria & Granistone S/A \\
Rain Forest & GRF & Granite & Meruoca & Granus S/A \\
Red Dragon & GRD & Granite & Sobral & Imarf-Limestone e \\
Green Galaxy & GGG & Granite & Granitos S/A \\
Verde Ventura & GVV & Granite & Massapê & Imarf-Limestone e \\
JuParaná Tropical & GJPT & Granite & Massapên e S/A \\
Branco São Paulo & GBSP & Granite & Santa Quitéria & Multigran Ltd.a. \\
Branco Acarapé & MBA & Marble & Acarape & Grandigran Ltd.a.
\end{tabular}




\subsection{Characterization of Natural Stones}

The chemical composition of the natural stones was determined by $\mathrm{X}$-ray fluorescence spectroscopy (model EDX 720, Shimadzu, Kyoto, Japan). The mineralogical phases were identified by X-ray diffraction (model XRD 6000, Shimadzu, Kyoto, Japan), with $\mathrm{CuK} \alpha$ $(40 \mathrm{kV} / 30 \mathrm{~mA}), 2 \theta$ interval between $5^{\circ}-60^{\circ}$ and $0.02^{\circ}$ step. The diffraction peaks observed were indexed using the Search Match ${ }^{\circledR}$ Program and the JCPDS database. The thermal behavior was evaluated by differential thermal analysis (model RB-3000, Instrumentec BP, Campinas, Brazil), where the samples were heated to $12.5^{\circ} \mathrm{C} \cdot \mathrm{min}^{-1}$ from room temperature to $1000{ }^{\circ} \mathrm{C}$. All DTA experiments were conducted under a compressed-air atmosphere.

The morphology and petrographic features of the natural stones were investigated by an optical stereo microscope. The images were acquired using an microscope (Zeizz, Axiotech) coupled to a digital camera (ColorView Soft Imaging System-II) and analySIS ${ }^{\circledR}$ software (Version 2.3). This technique was used to identify the minerals and to characterize their microstructure.

\subsection{Physical-Mechanical Properties}

The physical properties of the natural stones (apparent density-AD, apparent porosity-AP, and water absorption - WA) were determined following ASTM C-97/C97M [32]. For this, 12 samples with dimensions of $50 \mathrm{~mm} \times 50 \mathrm{~mm} \times 50 \mathrm{~mm}$ were used. The experiments to determine the thermal expansion coefficient (CTE) were recorded using a dilatometer RB-3000 by BP Engineering. These tests were performed on three cylindrical samples $\left(15 \times 50 \mathrm{~mm}\right.$ in length), previously dried in an oven at $60^{\circ} \mathrm{C}$ for $48 \mathrm{~h}$, under identical experimental conditions. The samples were heated at $5{ }^{\circ} \mathrm{C} \cdot \mathrm{min}^{-1}$ from $25^{\circ} \mathrm{C}$ to $300^{\circ} \mathrm{C}$. In order to stabilize the equipment, it was kept at $30^{\circ} \mathrm{C}$ for $30 \mathrm{~min}$. The $\mathrm{CTE}$ values were calculated in 2 temperature ranges: $30^{\circ} \mathrm{C}$ to $50{ }^{\circ} \mathrm{C}$ and $40{ }^{\circ} \mathrm{C}$ to $100{ }^{\circ} \mathrm{C}$.

The mechanical compression strength experiments were accomplished in a universal testing machine (INSTRON EMIC, model DL 1000). Five samples with dimensions of $70 \mathrm{~mm} \times 70 \mathrm{~mm} \times 70 \mathrm{~mm}$ were used, and all experiments were performed with a 200 ton load cell and a test speed of $1.0 \mathrm{~mm} \cdot \mathrm{min}^{-1}$ following the ASTM C-170/C170M standard [33]. The rupture modulus was determined from the 3-point flexural strength test on a universal testing machine (EMIC, DL 1000), with a distance between the support points of $180 \mathrm{~mm}$ and a test speed of $1.0 \mathrm{~mm} \cdot \mathrm{min}^{-1}$. The experiments were carried out on five samples with dimensions of $200 \mathrm{~mm} \times 100 \mathrm{~mm} \times 50 \mathrm{~mm}$ following ASTM C-99/C99M and C-880/C880M [34,35].

The impact resistance was determined from the hard body impact test. The experiment consisted of letting a steel ball with a mass of $1 \mathrm{~kg}$ fall on the test pieces with dimensions of $200 \mathrm{~mm} \times 200 \mathrm{~mm} \times 30 \mathrm{~mm}$. The steel ball was released at an initial height of $0.2 \mathrm{~m}$. The initial height was increased by $0.05 \mathrm{~m}$ until the rupture of the specimen. For each experimental condition, five samples were used. The result was obtained using the average drop height for which there was a sample rupture. The abrasion resistance values were determined by the abrasion wear test on an Amsler abrasimeter (Contenco, I-4212). Five samples with dimensions of $70 \mathrm{~mm} \times 70 \mathrm{~mm} \times 40 \mathrm{~mm}$ were used. Dry sand was used as an abrasive at a flow of $72 \mathrm{~cm}^{3} \mathrm{~min}^{-1}$. After 500 and 1000 turns, the wear was measured according to the ASTM C-241/C241M standard [36].

\subsection{Resistance to Chemical Attack}

Resistance to chemical attack analysis was carried out to assess the behavior of natural stones in the presence of chemical substances present in daily use. Five chemical reagents were used: ammonium chloride $\left(\mathrm{NH}_{4} \mathrm{Cl}\right)$, sodium hypochlorite $(\mathrm{NaClO})$, citric acid $\left(\mathrm{C}_{6} \mathrm{H}_{8} \mathrm{O}_{7}\right)$, hydrochloric acid $(\mathrm{HCl})$, and potassium hydroxide $(\mathrm{KOH})$. The tests were performed according to the ISO 10545-13 standard [37]. Table 2 shows the concentrations of each reagent and the exposure time of the samples during the experiment. 
Table 2. Concentration and exposure time of the reagents used in the chemical attack resistance test.

\begin{tabular}{ccccc}
\hline Reagent & Formula & $\mathbf{p H}$ & Concentration & Exposure Time \\
\hline Ammonium chloride & $\mathrm{NH}_{4} \mathrm{Cl}$ & 5.0 & $100 \mathrm{~g} / \mathrm{L}$ & $24 \mathrm{~h}$ \\
Sodium hypochlorite & $\mathrm{NaClO}$ & 8.0 & $20 \mathrm{mg} / \mathrm{L}$ & $24 \mathrm{~h}$ \\
Citric acid & $\mathrm{C}_{6} \mathrm{H}_{8} \mathrm{O}_{7}$ & 1.2 & $100 \mathrm{~g} / \mathrm{L}$ & $24 \mathrm{~h}$ \\
Hydrochloric acid & $\mathrm{HCl}$ & 1.0 & $3 \%(\mathrm{v} / \mathrm{v})$ & $96 \mathrm{~h}$ \\
Potassium hydroxide & $\mathrm{KOH}$ & 14.0 & $30 \mathrm{~g} / \mathrm{L}$ & $96 \mathrm{~h}$ \\
\hline
\end{tabular}

Six samples of each natural stone with dimensions of $100 \mathrm{~mm} \times 100 \mathrm{~mm} \times 20 \mathrm{~mm}$ were used for the experimental conditions of the chemical resistance test (Table 2). All samples were polished, weighed, and analyzed for surface brightness with the Gloss Meter (Horiba, Gloss Checker 16.310). Then, one of the six samples was separated to be used as a blank. In the other five samples, PVC tubes with a diameter of $75 \mathrm{~mm}$ were fixed on the surface, and $50 \mathrm{~mL}$ of the reagents was introduced. The tubes were sealed with PVC films to avoid evaporation of the reagents. After a specific exposure time (Table 2), the PVC tubes were removed. The exposed surfaces were washed with running water, dried naturally, and subjected to new brightness measures (average of 10 readings). After exposure to the different substances, the samples were weighed again to assess the loss of mass.

\section{Results and Discussion}

\subsection{Chemical Composition, Mineralogical Phases, and Thermal Behavior of Natural Stones}

The chemical analysis, mineralogical phases, and the differential thermal analysis (DTA) curves measured from the limestones investigated in this study are listed in Table 3, Figure 1, and Figure 2, respectively. $\mathrm{CaO}$ and $\mathrm{MgO}$ were the major components detected in the limestones LCA, LCB, LBC, and LBM. This result is in accordance with X-ray diffraction (XRD) patterns, where the mineralogical phases calcite (JCPDS 47-1743) and dolomite (JCPDS: 89-5862) were identified in these samples (see Figure 1). The LCC, LMC, and LBSM samples presented only the calcite phase (JCPDS 47-1743). This result agrees with the chemical analysis, since $\mathrm{MgO}$ contents were not identified in these samples (see Table 3). Based on the MgO content, the LCC, LMC, and LBSM samples were classified as calcitic limestones $(\mathrm{MgO}<1.1 \%)$; the LCA, LBC, and LCB samples as magnesian limestones $(1.1 \%$ $<\mathrm{MgO}<2.1 \%)$; and the LBM sample as dolomitic limestone $(2.1 \%<\mathrm{MgO}<10.8 \%)$ [38]. The presence of low levels of $\mathrm{SiO}_{2}, \mathrm{Al}_{2} \mathrm{O}_{3}, \mathrm{Fe}_{2} \mathrm{O}_{3}, \mathrm{TiO}_{2}$, and $\mathrm{SO}_{3}$ detected on the limestones is probably related to impurities such as clays, feldspars, micas, quartz, and sulfides, among others [39].

In some DTA curves of the limestones (Figure 2), more precisely in the LCC, LMC, and LBSM samples, an endothermic peak was observed at approximately $950{ }^{\circ} \mathrm{C}$. This thermal event is related to the decomposition of calcite $\left(\mathrm{CaCO}_{3} \rightarrow \mathrm{CaO}+\mathrm{CO}_{2}\right)$. In the LCA, LCB, LBC, and LBM samples, two endothermic peaks were observed; the first peak $\left(\sim 800^{\circ} \mathrm{C}\right)$ is probably associated with the decomposition of magnesium carbonate $\left(\mathrm{MgCO}_{3} \rightarrow \mathrm{MgO}+\mathrm{CO}_{2}\right)$ (see Figure 1$)$ and the second peak $\left(\sim 950^{\circ} \mathrm{C}\right)$ is associated with calcite decomposition.

Table 3. Chemical composition of the limestones investigated in this study.

\begin{tabular}{|c|c|c|c|c|c|c|c|c|c|c|}
\hline \multirow{2}{*}{ Samples } & \multicolumn{10}{|c|}{ Oxides (\%mass) } \\
\hline & $\mathrm{CaO}$ & $\mathrm{MgO}$ & $\mathrm{SiO}_{2}$ & $\mathrm{Al}_{2} \mathrm{O}_{3}$ & $\mathrm{~K}_{2} \mathrm{O}$ & $\mathrm{Na}_{2} \mathrm{O}$ & $\mathrm{Fe}_{2} \mathrm{O}_{3}$ & $\mathrm{TiO}_{2}$ & $\mathrm{SO}_{3}$ & Others \\
\hline LCC & 93.7 & & 1.3 & 2.8 & 0.2 & & 0.5 & & 1.0 & 0.5 \\
\hline LCA & 88.1 & 4.9 & 2.0 & & 0.3 & & 2.3 & & 1.6 & 0.8 \\
\hline LCB & 90.7 & 3.2 & 3.1 & 1.3 & 0.4 & & 0.4 & & 0.8 & 0.1 \\
\hline LMC & 96.3 & & 1.5 & 0.7 & 0.2 & & 0.4 & & 0.8 & 0.1 \\
\hline LBC & 90.4 & 3.0 & 3.0 & 1.3 & 0.3 & & 0.7 & & 1.2 & 0.1 \\
\hline LBM & 80.4 & 11.3 & 3.8 & 1.6 & 0.3 & & 0.8 & & 1.7 & 0.1 \\
\hline LBSM & 95.9 & & 1.7 & & 0.2 & & 0.8 & & 1.2 & 0.2 \\
\hline
\end{tabular}



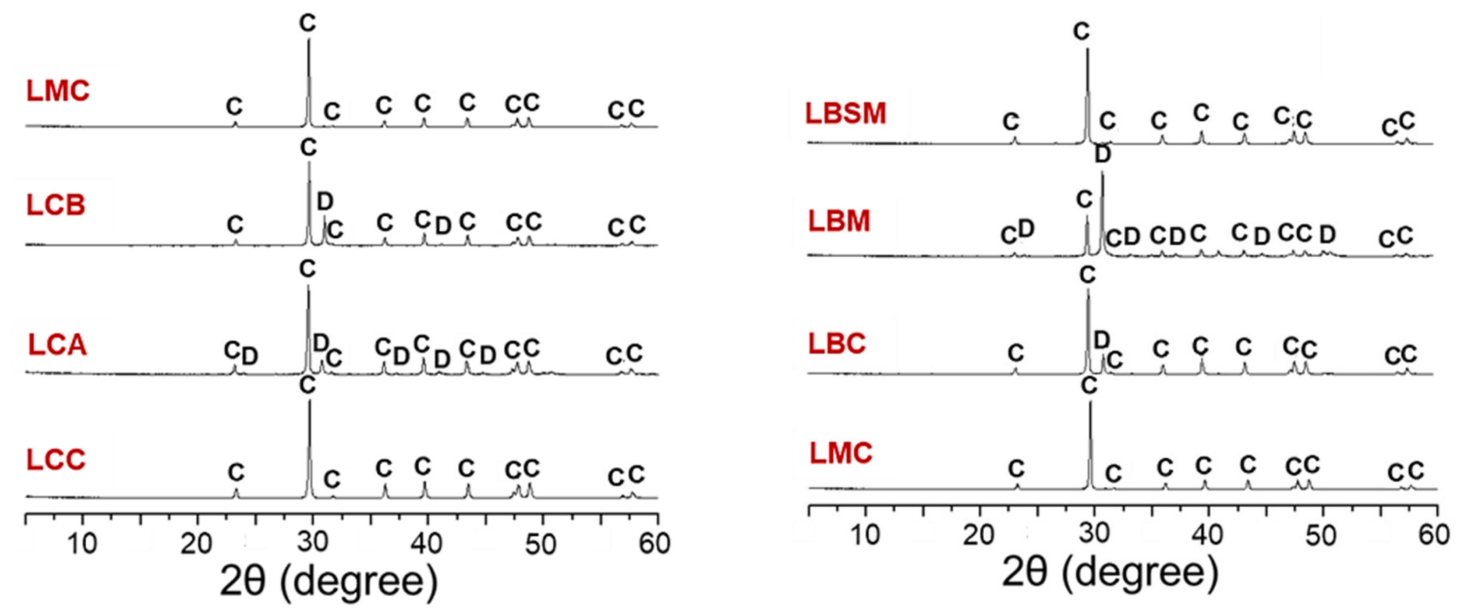

Figure 1. X-ray diffraction patterns of limestones. C—calcite, D—dolomite.
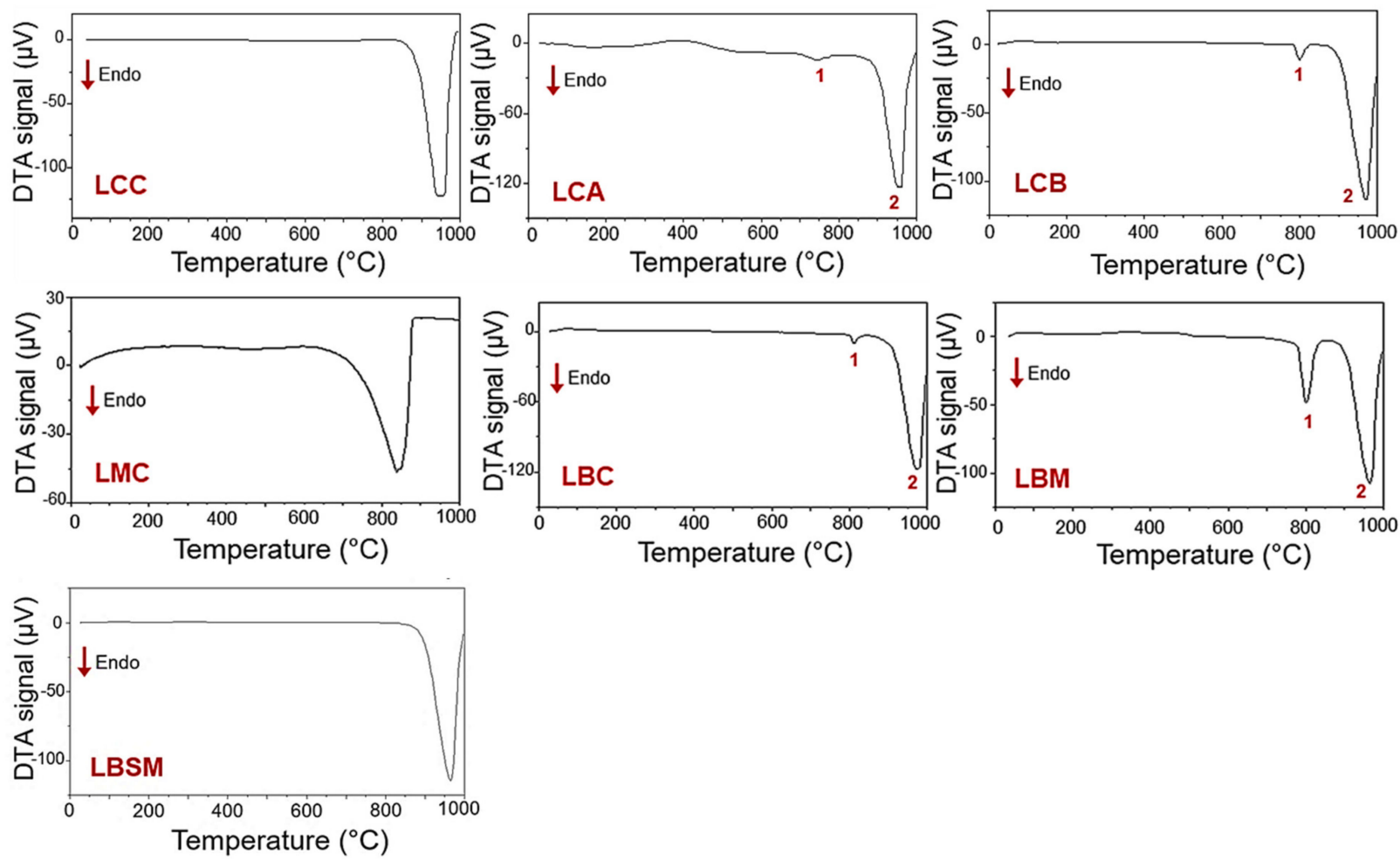

Figure 2. Differential thermal analysis (DTA) curves measured from the limestone samples (LCC, LCA, LCB, LMC, LBC, LBM, and LBSM).

Table 4 and Figures 3 and 4 show the chemical analysis, the mineralogical phases, and the DTA curves measured from the granite samples. Quartz (JCPDS 46-045), feldspars, and mica (JCPDS 83-1808) were the main mineralogical phases identified in the GBC, GRF, GRD, GGG, GVV, GJPT, and GBSP samples (see Figure 3). In general, the granite matrix consisted of the feldspars orthoclase (potassium feldspar, JCPDS 31-0966) and plagioclase (calcium-sodium feldspar, JCPDS 41-1486). These results agree with the chemical composition, which indicated high levels of $\mathrm{K}_{2} \mathrm{O}, \mathrm{Na}_{2} \mathrm{O}$, and $\mathrm{CaO}$ oxides in these materials. $\mathrm{Fe}_{2} \mathrm{O}_{3}$ and $\mathrm{SO}_{3}$ contents were also detected, which indicates the probable presence of sulfides. The reddish and pink color presented by some granites was probably associated with hematite inclusions in the feldspar [40]. The presence of feldspar is significant for the mechanical behavior of granites, because in these materials, the resistance is closely associated with the content of feldspar, quartz, and mica and their granulometry [41,42]. As the quartz 
content increases, the mechanical strength of granite tends to increase. However, the high content of feldspars causes a reduction in mechanical properties due to these being easily cleavable minerals that have a tendency to suffer weathering. The presence of mica also compromises the strength of the stones because of the low hardness presented by this mineral (Mohs hardness 2-4) [43,44]. A small amount of kaolinite (JCPDS 78-2110) was identified in the GGG and GRD samples as a secondary mineral. In granite, the presence of kaolinite usually occurs as an impurity but can also be formed from the wear of feldspars if the removal of cations occurs intensely [45].
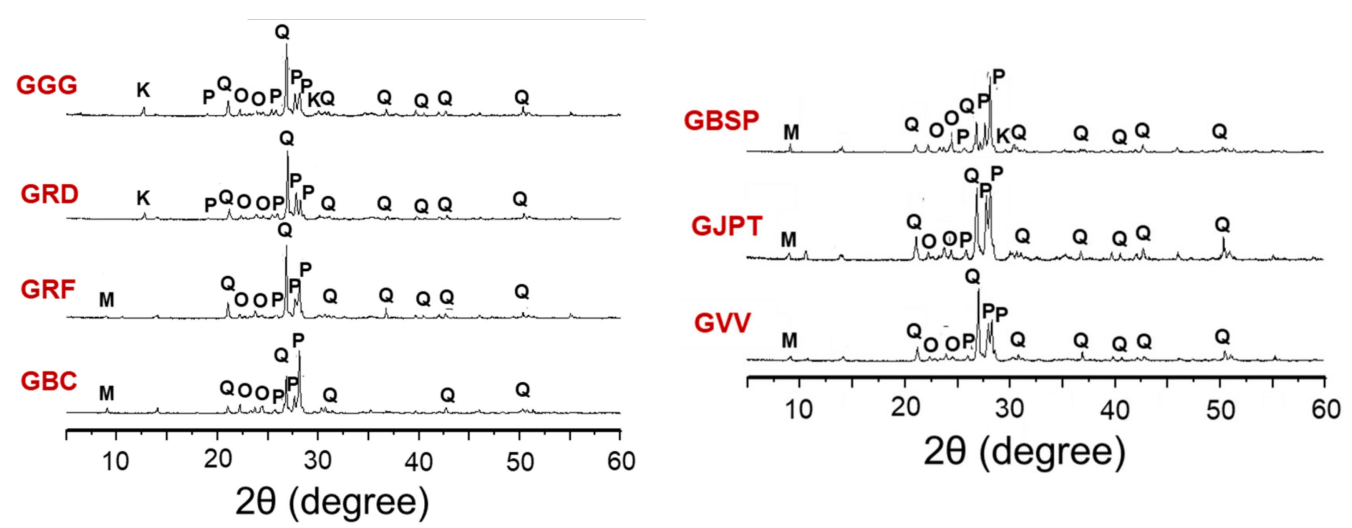

Figure 3. X-ray diffraction patterns of granites. $\mathrm{M}-$ mica, $\mathrm{K}-$ kaolinite, $\mathrm{P}-$ plagioclase, $\mathrm{O}$-orthoclase, and $\mathrm{Q}-\mathrm{quartz}$.
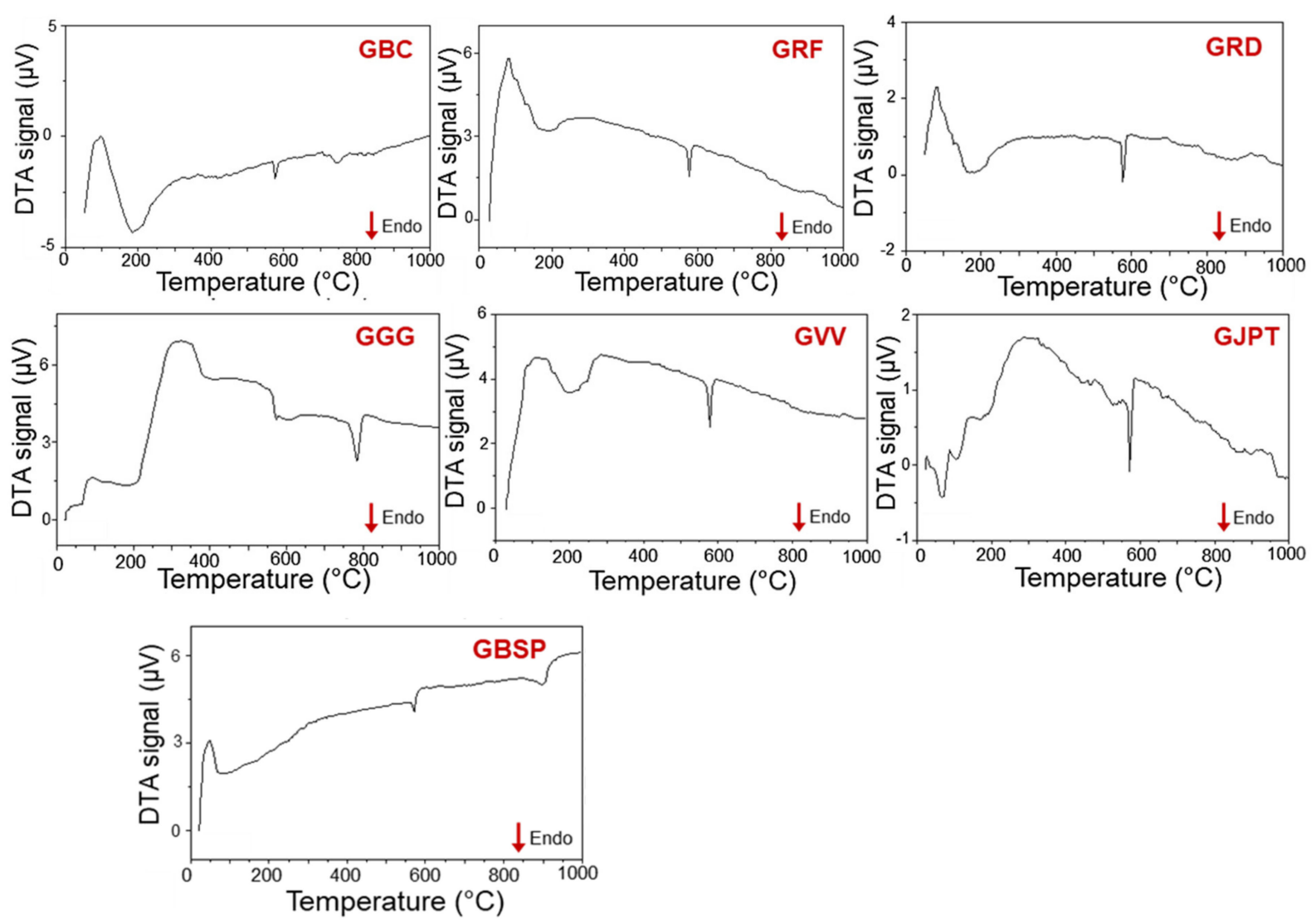

Figure 4. DTA curves obtained from granites (GBC, GRF, GRD, GGG, GVV, GJPT, and GBSP) samples. 
Table 4. Chemical composition of the granites investigated in this study.

\begin{tabular}{ccccccccccc}
\hline \multirow{2}{*}{ Samples } & \multicolumn{10}{c}{ Oxides (\%mass) } \\
\cline { 2 - 10 } & $\mathbf{C a O}$ & $\mathbf{M g O}$ & $\mathbf{S i O}_{\mathbf{2}}$ & $\mathbf{A l}_{\mathbf{2}} \mathbf{O}_{\mathbf{3}}$ & $\mathbf{K}_{\mathbf{2}} \mathbf{O}$ & $\mathbf{N a}_{\mathbf{2}} \mathbf{O}$ & $\mathbf{F e}_{\mathbf{2}} \mathbf{O}_{\mathbf{3}}$ & $\mathbf{T i O}_{\mathbf{2}}$ & $\mathbf{S O}_{\mathbf{3}}$ & $\mathbf{O t h e r s}$ \\
\hline GBC & 1.4 & & 66.8 & 17.4 & 3.9 & 7.3 & 1.5 & & 1.2 & 0.5 \\
GRF & 2.1 & 70.0 & 14.6 & 5.2 & 1.3 & 4.2 & 0.3 & 1.3 & 1.0 \\
GRD & 0.8 & 66.7 & 16.0 & 7.2 & 1.0 & 5.9 & 0.6 & 1.1 & 0.7 \\
GGG & 3.8 & 63.0 & 16.9 & 4.8 & 2.3 & 6.2 & 0.6 & 1.2 & 1.2 \\
GVV & 1.4 & 69.3 & 14.4 & 5.5 & 3.0 & 2.7 & 0.2 & 2.3 & 1.2 \\
GJPT & 1.7 & 67.5 & 14.4 & 5.6 & 5.1 & 3.9 & 0.4 & 1.0 & 0.4 \\
GBSP & 1.0 & 70.2 & 18.3 & 4.8 & 2.7 & 0.5 & & 1.3 & 1.2 \\
\hline
\end{tabular}

In the DTA curves of the granite samples (Figure 4), it was possible to identify the presence of two endothermic events $\left(\sim 200^{\circ} \mathrm{C}\right.$ and $\sim 573{ }^{\circ} \mathrm{C}$, respectively). The first event is probably associated with the elimination of free water, and the second with the polymorphic transformation of quartz $(\alpha \rightarrow ß)$ [7]. The GGG sample had a small endothermic band at $\sim 600^{\circ} \mathrm{C}$ and an endothermic peak around $780^{\circ} \mathrm{C}$. These events are possibly related to the decomposition of kaolinite and calcite present in this material, respectively.

The chemical analysis of the marble investigated in this study is listed in Table 5. The mineralogical phases and DTA curve are shown in Figure 5a,b. It was possible to observe that dolomite (JCPDS: 89-5862) was the predominant mineralogical phase (Figure 5a). Traces of the calcite phase were also identified (JCPDS 47-1743). These results are in accordance with the chemical analysis (Table 5), in which the dolomitic limestone character was confirmed by the high content of $\mathrm{MgO}$ detected. The presence of $\mathrm{SiO}_{2}$ may be related to impurities such as quartz and feldspars. High levels of $\mathrm{SiO}_{2}$ (above 7\%) are essential to give the material the compatible mechanical strength for use as natural stone tiles for civil construction. Two endothermic events were also observed in the MBA sample; the first thermal event $\left(\sim 800^{\circ} \mathrm{C}\right)$ is associated with the decomposition of magnesium carbonate, and the second $\left(\sim 950^{\circ} \mathrm{C}\right)$ with the decomposition of calcium carbonate [6].

Table 5. The chemical composition of the marble investigated in this study.

\begin{tabular}{ccccccccccc}
\hline \multirow{2}{*}{ Samples } & \multicolumn{10}{c}{ Oxides (\%mass) } \\
\cline { 2 - 11 } & $\mathrm{CaO}$ & $\mathbf{M g O}$ & $\mathrm{SiO}_{2}$ & $\mathrm{Al}_{2} \mathrm{O}_{3}$ & $\mathrm{~K}_{\mathbf{2}} \mathrm{O}$ & $\mathrm{Na}_{\mathbf{2}} \mathrm{O}$ & $\mathrm{Fe}_{2} \mathrm{O}_{3}$ & $\mathrm{TiO}_{2}$ & $\mathrm{SO}_{3}$ & Others \\
\hline MBA & 61.4 & 28.2 & 7.3 & 0.7 & 0.2 & & 0.8 & 1.1 & 0.3 \\
\hline
\end{tabular}
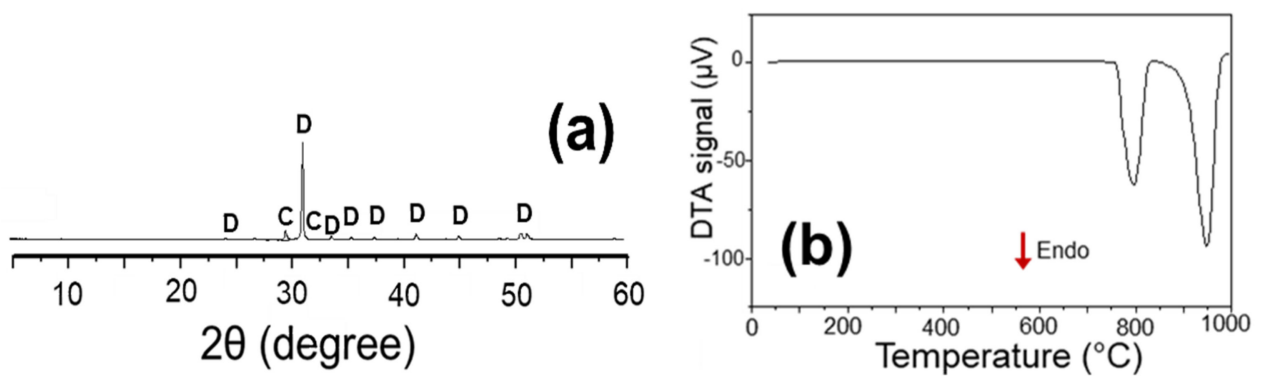

Figure 5. X-ray diffraction pattern (a) and DTA curve (b) obtained from the marble sample. C—calcite, D—dolomite.

\subsection{Morphology and Microstructure of Natural Stones}

Figure 6 shows optical stereo micrographs obtained from the surface of the limestones (LCC, LCA, LCB, LMC, LBC, LBM, and LBSM). Although crystals with sizes greater than $500 \mu \mathrm{m}$ were observed in the LBC and LBM samples, most samples (i.e., LBSM, LCB, LMC, LCC, LCA) presented crystals with sizes smaller than $100 \mu \mathrm{m}$. The different crystal sizes in the limestones are directly related to the chemical composition variation in these samples. No amount of $\mathrm{MgO}$ (LCC, LMC, and LSM) and $\mathrm{Al}_{2} \mathrm{O}_{3}$ (LCA and LBSM) were detected in 
some samples. LCC is a limestone rock with a sedimentary and monocrystalline nature. It has a massive structure with a microcrystalline bioclastic texture. It also has scattered fossil structures with elongated shapes of approximately $0.5 \mathrm{~cm}$, whose composition is $99 \%$ carbonates (formed by very fine calcium compounds). It has a predominantly light to dark beige color, with yellow tones. LCA is similar to LCC. It presents a whitish-gray color when it dries, and when wet, it becomes bluish gray. When dispersed, it presents beige lines, with orientation in the form of waves, which likely indicates the conditions of origin.
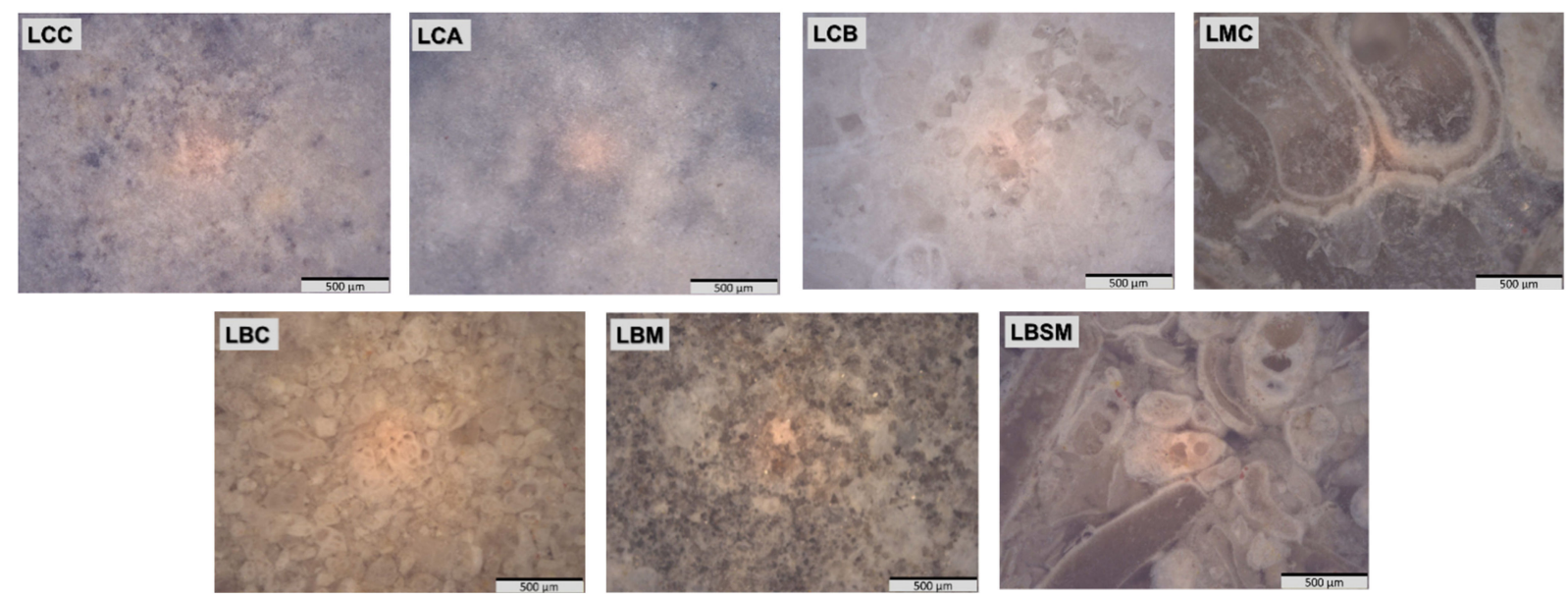

Figure 6. Optical stereomicrographs obtained from the surface of limestones.

LCB has a massive structure with fine to medium monocrystals. It has a microcrystalline texture, with a composition of $95 \%$ carbonates in the form of concentric aggregates of inorganic origin, with very fine $\mathrm{CaO}$ compounds predominating and $3 \% \mathrm{MgO}$. Quartz is present with a $3 \%$ content, in the form of sub-rounded clasts with an average size of $0.7 \mathrm{~cm}$. LMC and LBC show similar characteristics to LCB, which indicates the same mineral formation. The three stones are light beige and have dark pigmentation with elongated shapes of up to $0.5 \mathrm{~cm}$, originating from different fossils. LBM and LBSM have similar structures to LBC. LBM is composed of magnesian carbonates (above 10\%) and is calcitic (greater than $80 \%$ ). The quartz content approaches $4 \%$. It has a light beige color, with dark pigmentation originating from different fossils. LBSM has 95\% calcium carbonates and approximately $2 \%$ quartz. It has a whitish-gray color, with variegated pigments also originating from other fossils.

The presence of bioclast in the limestones can significantly influence the physical and mechanical behavior of this rock. Studies [46] observed a bioclast contribution to limestone rock porosity, with micropores embedded in the bioclasts. Despite a relatively minor contribution to the total porosity, these micropores can negatively influence the mechanical strength of the material. Studies $[47,48]$ also observed that bioclasts could contribute with macropores $(50-300 \mu \mathrm{m})$ and with micropores $(5-10 \mu \mathrm{m})$ in other calcareous porous rocks, and that under stress, the development of the conjugate shear bands were accompanied by damage in the form of Hertzian fractures emanating from bioclast contacts, with grain crushing and pore collapse. Naeem et al. [49] observed that the strength of the rock increased with increased calcite content but linearly decreased with a rise in the number of bioclasts.

Figure 7 shows optical stereomicrographs obtained from the surface of granites (GBC, GRF, GRD, GGG, GVV, GJPT, and GBSP). In general, the crystals observed in the granite samples were larger than $500 \mu \mathrm{m}$. However, in GBC, GBSP, and GGG samples, small crystals $(<200 \mu \mathrm{m})$ were immersed in the matrix. These samples present medium to coarse and isotropic granulation, with an atypical granular phaneritic texture, characterized by prismatic quartz crystals with trapezoidal terminations immersed in a feldspar matrix containing Muscovites. This differs from other granites in that it is hololeucocratic and 
white with porphyry of feldspar and quartz. GRF is a coarse, equigranular granite with a sieno-granitic composition. It shows no signs of deformation and is essentially composed of potassium feldspar, quartz, and biotite. Potassium feldspar occurs in the form of crystals that easily reach $1 \mathrm{~cm}$, exhibiting various shades of green. Quartz occurs in the form of sub-rounded to hexagonal crystals and varies from 0.2 to $0.5 \mathrm{~cm}$. When quartz is in contact with K-feldspars, it acquires a pseudo-green color. Biotite occurs in lamellar clusters and may exceed $0.5 \mathrm{~cm}$ in thickness.
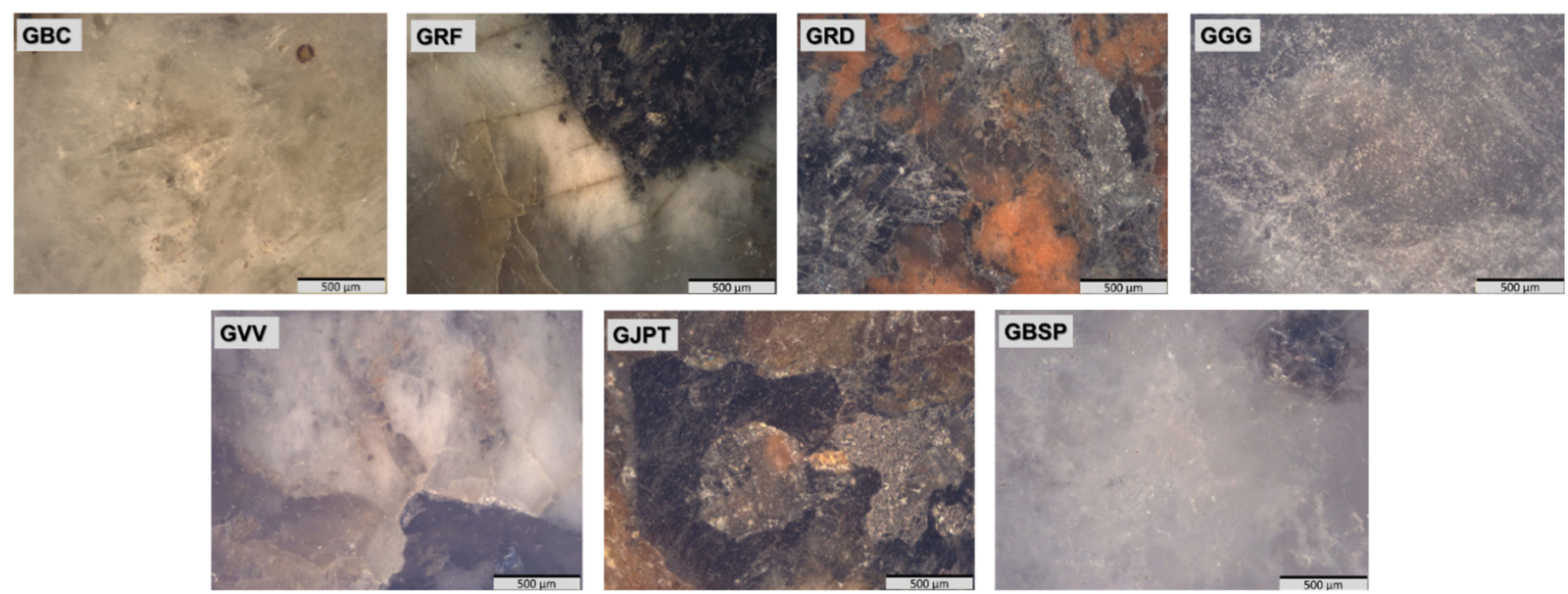

Figure 7. Optical stereomicrographs obtained from the surface of granites.

GRD is classified as biotite-magnetite granite. It presents an intense red color, is medium to coarse-grained, and is composed predominantly of mega crystals of potassium feldspar (approximately $53 \%$ ) and subordinately by smaller crystals of quartz (18\%), plagioclase $(12 \%)$, and biotite lamellas (5\%). GGG is a coarse granite that presents an intense fracturing on the entire surface, mainly in the quartz crystals. In feldspar crystals, both potassium and plagioclase, the microcracks and interstices on the surface hide the distinct characteristics of these two formations.

GVV is a sieno-granitic rock. It has a greenish to slightly yellowish color and medium to coarse grain. It consists essentially of quartz, feldspar, biotite, and amphibole. Potassium feldspar occurs in the form of crystals that easily reach $1 \mathrm{~cm}$, exhibiting various shades of green. Quartz occurs in the form of sub-rounded to hexagonal crystals and varies from 0.2 to $0.5 \mathrm{~cm}$. The biotite, reddish-brown in color, occurs in lamellar clusters and may exceed $0.5 \mathrm{~cm}$ in thickness. GJPT is a sieno-granitic rock with an ocher brown color. The color is likely due to weathering (oxidation and hydration of minerals containing ferrous iron). They have reddish-brown grain edges that accentuate the color of the rock. It has a milky white color and a fine to medium granular texture and shows some medium-grained crystals. It is essentially formed by feldspars, quartz, and gray-colored micas.

\subsection{Physical-Mechanical Properties}

Table 6 lists the results of the analysis of the physical properties (apparent density (AD), apparent porosity (AP), and water absorption (WA)), mechanical properties (compressive strength (CS), flexural strength (FS), impact resistance (IHB), and abrasion wear test (AW)) and the coefficients of thermal expansion measures in the limestone, granite, and marble samples. Table 7 contains a comparative and qualitative analysis of these results, classifying the investigated natural stones as low, regular, medium, good, or excellent for use as natural stone tiles in civil construction.

All limestones studied showed AD values between $2.25 \mathrm{~g} / \mathrm{cm}^{3}$ and $2.52 \mathrm{~g} / \mathrm{cm}^{3}$. According to ASTM C568/C568M [50], the limestones for application in civil construction can be classified into three categories: low density $\left(1.76 \mathrm{~g} / \mathrm{cm}^{3}\right.$ to $\left.2.16 \mathrm{~g} / \mathrm{cm}^{3}\right)$, medium density $\left(2.16 \mathrm{~g} / \mathrm{cm}^{3}\right.$ to $\left.2.56 \mathrm{~g} / \mathrm{cm}^{3}\right)$, and high density $\left(>2.56 \mathrm{~g} / \mathrm{cm}^{3}\right)$. Therefore, in agreement with 
ASTM C568/C568M, the limestones investigated in this study are classified as medium density. Among the limestones, the LCA stood out for presenting the lowest values of porosity $(1.88 \%)$ and water absorption $(0.75 \%)$. On the other hand, LMC showed the highest values, with $13.74 \%$ and $6.11 \%$ apparent porosity and water absorption, respectively. Vigroux et al. [51] evaluated six types of limestone from different regions of France and found porosity values of $11.2-25 \%$. Studies by Eslami et al. [52] report limestone with porosity values of $10-35 \%$. According to some studies [53-55], limestones for application as natural stone tiles in civil construction must have less than $4 \%$ apparent porosity. However, the applicability of limestones as natural stone tiles depends on the type and location of application. Thus, there are reports of materials used as natural stone tiles with a porosity range of $10 \%$ to $45 \%$ [56-59].

The water absorption of the studied granites was in the range of $0.1-0.3 \%$. These values are compatible with those found in commercial granites (WA between 0.1 and $0.8 \%$ ) [30]. In general, the results of the physical properties of granite and marble exceeded the average values suggested by ASTM C615/C615M [60]. All granites presented AP values $<1 \%$, WA values $<0.4 \%$, and an AD (dry) $>2.56 \mathrm{~g} / \mathrm{cm}^{3}$. The GGG sample presented better experimental results $\left(\mathrm{AD}=2.69 \mathrm{~g} / \mathrm{cm}^{3}, \mathrm{AP}=0.35 \%\right.$, and $\left.\mathrm{WA}=0.14 \%\right)$, while the GRD presented values closer to the limit established by the standard $\left(A D=2.60 \mathrm{~g} / \mathrm{cm}^{3}\right.$, $\mathrm{AP}=0.81 \%$, and $\mathrm{WA}=0.31 \%$ ). Granites are also suitable for application in conditions with exposure to the environment since they have less than $3 \%$ porosity $[21,44,61,62]$.

Comparing the WA results of limestone, granite, and marble with the criteria established by ISO 13006 [63], it is noted that granite and marble would be comparable, in terms of WA, with porcelain tiles (WA $\leq 0.5 \%$ ). In comparison, LCC and LCB samples have WA equivalent to that of stoneware $(0.5 \%<\mathrm{WA}<3.0 \%)$, and LCA, LMC, LBC, LBM, and LBSM samples have WA equivalent to semi-stoneware $(3.0 \%<\mathrm{WA}<6.0 \%)$. This shows that, although limestones have high porosities for natural stones, they present water absorption values that allow use as natural stone tiles [63].

Regarding the thermal expansion coefficients, the limestones present values in the range of $4.5-6.0 \times 10^{-6}{ }^{\circ} \mathrm{C}^{-1}\left(30^{\circ} \mathrm{C}-50{ }^{\circ} \mathrm{C}\right)$. Harvey [64] determined the expansion coefficient of 39 various limestone specimens and observed that the expansion coefficient varied from 1.9 to $6.1 \times 10^{-6}{ }^{\circ} \mathrm{C}$ in the range from room temperature to $100{ }^{\circ} \mathrm{C}$. The determination of the thermal expansion coefficient of natural stones is of great importance for civil construction applications, as the rocks undergo volume variation (expansion or contraction) when subjected to temperature fluctuations. Thus, this coefficient is used for calculations in the dimensioning of expansion joints for slabs, panels, and tiles. Ideally, for this application, the material has the lowest thermal coefficients to avoid the appearance of cracks during the expansion and contraction process, which would reduce the mechanical strength of the material.

For granites, the range of variation of the expansion coefficient is wider $\left(7.7-11 \times 10^{-6}{ }^{\circ} \mathrm{C}^{-1}\right)$; this is probably related to differences in microstructural characteristics, such as quartz content, feldspar content (constitutes the matrix), and presence of other phases. It is known that the degree of thermal expansion in natural stones depends mainly on their mineralogical composition (especially the content of quartz and calcite) and orientation of the crystal. Each mineral has different thermal expansion values, and some are anisotropic. For example, quartz has the highest thermal expansion coefficient $(\alpha)$ perpendicular to the c axis $\left(\alpha=13 \times 10^{-6}{ }^{\circ} \mathrm{C}^{-1}\right)$ and the smallest parallel to it $\left(7.7 \times 10^{-6}{ }^{\circ} \mathrm{C}^{-1}\right)$ [65]. Granites with high plagioclase content generally have low $\alpha$ values because this mineral has minimal volume expansion. Also, the thermal expansion depends on factors such as porosity, grain size, and temperature. The expansion coefficient decreases with increasing porosity and increases with increasing temperature, grain size, or quartz content $[66,67]$. The thermal expansion coefficient for commercial granites ranges from 5.0 to $10.28 \times 10^{-6}{ }^{\circ} \mathrm{C}^{-1}$ [68]. 
Table 6. Physical properties, thermal expansion coefficients, and mechanical properties of limestones, granites, and marble.

\begin{tabular}{|c|c|c|c|c|c|c|c|c|c|c|c|}
\hline \multirow{3}{*}{ Samples } & \multicolumn{4}{|c|}{ Physical Properties $^{1}$} & \multirow{2}{*}{\multicolumn{2}{|c|}{$\begin{array}{c}\text { Thermal Expansion } \\
\text { Coefficient }^{2} \\
\left(10^{-6}{ }^{\circ} \mathrm{C}^{-1}\right)\end{array}$}} & \multicolumn{5}{|c|}{ Mechanical Properties } \\
\hline & \multicolumn{2}{|c|}{ Apparent Density $\left(\mathrm{g} / \mathrm{cm}^{3}\right)$} & \multirow{2}{*}{$\begin{array}{l}\text { Apparent } \\
\text { Porosity } \\
\quad(\%)\end{array}$} & \multirow{2}{*}{$\begin{array}{c}\text { Water } \\
\text { Absorption } \\
\text { (\%) }\end{array}$} & & & \multirow{2}{*}{$\begin{array}{l}\text { Compressive } \\
\text { Strength }^{1} \\
\text { (MPa) }\end{array}$} & \multirow{2}{*}{$\begin{array}{l}\text { Flexural } \\
\text { Strength }{ }^{1} \\
\text { (MPa) }\end{array}$} & \multirow{2}{*}{$\begin{array}{c}\text { Impact } \\
\text { Resistance }^{1}(\mathrm{~m})\end{array}$} & \multicolumn{2}{|c|}{$\begin{array}{c}\text { Abrasion Wear Test } \\
(\mathrm{mm})\end{array}$} \\
\hline & Dry & Saturated & & & $\begin{array}{l}30^{\circ} \mathrm{C} \text { to } \\
50^{\circ} \mathrm{C}\end{array}$ & $\begin{array}{l}40^{\circ} \mathrm{C} \text { to } \\
100{ }^{\circ} \mathrm{C}\end{array}$ & & & & 500 & 1000 \\
\hline LCC & $2.45 \pm 0.01$ & $2.50 \pm 0.01$ & $6.71 \pm 0.59$ & $2.75 \pm 0.17$ & 5.5 & 6.0 & $27.1 \pm 2.3$ & $14.9 \pm 2.2$ & $0.44 \pm 0.08$ & 2.56 & 5.06 \\
\hline LCA & $2.52 \pm 0.03$ & $2.53 \pm 0.01$ & $1.88 \pm 0.10$ & $0.75 \pm 0.06$ & 6.0 & 7.0 & $30.2 \pm 4.8$ & $24.7 \pm 2.3$ & $0.55 \pm 0.07$ & 1.09 & 2.29 \\
\hline LCB & $2.48 \pm 0.02$ & $2.53 \pm 0.02$ & $6.63 \pm 0.44$ & $2.72 \pm 0.28$ & 5.0 & 5.8 & $21.5 \pm 6.0$ & $13.2 \pm 1.8$ & $0.39 \pm 0.06$ & 2.85 & 5.59 \\
\hline LMC & $2.25 \pm 0.05$ & $2.39 \pm 0.05$ & $13.74 \pm 0.48$ & $6.11 \pm 0.21$ & 5.1 & 6.2 & $16.5 \pm 6.5$ & $3.4 \pm 0.2$ & $0.42 \pm 0.07$ & 8.90 & 11.53 \\
\hline LBC & $2.34 \pm 0.03$ & $2.45 \pm 0.02$ & $10.94 \pm 1.48$ & $4.73 \pm 0.58$ & 5.0 & 5.0 & $29.3 \pm 4.6$ & $6.0 \pm 0.4$ & $0.37 \pm 0.06$ & 5.78 & 8.85 \\
\hline LBM & $2.41 \pm 0.02$ & $2.49 \pm 0.01$ & $8.19 \pm 1.33$ & $3.43 \pm 0.56$ & 6.0 & 5.3 & $34.3 \pm 3.0$ & $6.2 \pm 0.6$ & $0.40 \pm 0.07$ & 5.30 & 8.59 \\
\hline LBSM & $2.37 \pm 0.05$ & $2.47 \pm 0.04$ & $10.12 \pm 1.74$ & $4.29 \pm 0.86$ & 4.5 & 5.1 & $34.1 \pm 3.9$ & $5.4 \pm 0.6$ & $0.37 \pm 0.06$ & 7.55 & 10.89 \\
\hline GBC & $2.62 \pm 0.01$ & $2.62 \pm 0.01$ & $0.60 \pm 0.02$ & $0.23 \pm 0.01$ & 8.5 & 9.8 & $211.6 \pm 21.2$ & $17.6 \pm 0.6$ & $0.53 \pm 0.06$ & 0.25 & 0.51 \\
\hline GRF & $2.62 \pm 0.01$ & $2.63 \pm 0.01$ & $0.43 \pm 0.03$ & $0.16 \pm 0.02$ & 7.7 & 9.0 & $96.4 \pm 1.7$ & $9.8 \pm 1.2$ & $0.60 \pm 0.04$ & 0.34 & 0.74 \\
\hline GRD & $2.60 \pm 0.01$ & $2.61 \pm 0.01$ & $0.81 \pm 0.05$ & $0.31 \pm 0.02$ & 8.8 & 8.7 & $115.6 \pm 9.6$ & $13.5 \pm 1.9$ & $0.56 \pm 0.04$ & 0.34 & 0.77 \\
\hline GGG & $2.69 \pm 0.01$ & $2.69 \pm 0.01$ & $0.35 \pm 0.09$ & $0.14 \pm 0.05$ & 9.0 & 8.8 & $122.6 \pm 8.5$ & $22.6 \pm 4.1$ & $0.55 \pm 0.07$ & 0.23 & 0.48 \\
\hline GVV & $2.62 \pm 0.01$ & $2.62 \pm 0.01$ & $0.80 \pm 0.05$ & $0.29 \pm 0.04$ & 9.0 & 9.0 & $95.2 \pm 9.8$ & $11.5 \pm 1.2$ & $0.60 \pm 0.03$ & 0.51 & 0.75 \\
\hline GJPT & $2.62 \pm 0.01$ & $2.62 \pm 0.01$ & $0.80 \pm 0.05$ & $0.29 \pm 0.04$ & 11.0 & 12.8 & $94.1 \pm 13.3$ & $13.6 \pm 2.8$ & $0.61 \pm 0.04$ & 0.43 & 0.88 \\
\hline GBSP & $2.64 \pm 0.01$ & $2.65 \pm 0.01$ & $0.30 \pm 0.04$ & $0.10 \pm 0.04$ & 9.0 & 8.7 & $125.5 \pm 10.9$ & $21.1 \pm 1.8$ & $0.75 \pm 0.03$ & 0.11 & 0.43 \\
\hline MBA & $2.86 \pm 0.02$ & $2.87 \pm 0.02$ & $0.31 \pm 0.07$ & $0.11 \pm 0.05$ & 6.0 & 8.8 & $91.6 \pm 7.8$ & $13.2 \pm 4.8$ & $0.72 \pm 0.05$ & 0.28 & 0.57 \\
\hline
\end{tabular}

${ }^{1}$ Medium values \pm standard deviation; ${ }^{2}$ Determined by dilatometry. 
Table 7. Comparative and qualitative analysis of the physical-mechanical properties of limestones, granites, and marble.

\begin{tabular}{|c|c|c|c|c|c|}
\hline \multirow{2}{*}{ Properties } & \multicolumn{5}{|c|}{ Qualification of Natural Stone } \\
\hline & Low & Regular & Medium & Good & Great \\
\hline Water absorption (\%) & $\begin{array}{c}(>3.0) \\
\text { LCB, LMC, LBC, } \\
\text { LBM, LBSM }\end{array}$ & $\begin{array}{l}(1.0-3.0) \\
\text { LCC }\end{array}$ & $\begin{array}{l}(0.4-1.0) \\
\text { LCA }\end{array}$ & $\begin{array}{l}(0.1-0.4) \\
\text { All granites }\end{array}$ & $(<0.1)$ \\
\hline Apparent Porosity (\%) & $\begin{array}{c}(>6.0) \\
\text { LCC, LCB, LMC, } \\
\text { LBC, LBM, LBSM }\end{array}$ & $(3.0-6.0)$ & $\begin{array}{c}(1.0-3.0) \\
\text { LCA }\end{array}$ & $\begin{array}{c}(0.5-1.0) \\
\text { GGG, GRF, GBSP }\end{array}$ & $\begin{array}{c}(<0.5) \\
\text { GBC, GRD, GVV, } \\
\text { GJPT }\end{array}$ \\
\hline $\begin{array}{l}\text { Expansion Coefficient } \\
\quad\left(\mathrm{mm} \times 10^{-3}\right)\end{array}$ & $(>12)$ & $\begin{array}{c}(10-12) \\
\text { GJPT }\end{array}$ & $\begin{array}{c}(8-10) \\
\text { GBC, GRD, GGG, } \\
\text { GVV, GBSP }\end{array}$ & $\begin{array}{c}(6-8) \\
\text { LCA, LBM, GRF, } \\
\text { MBA }\end{array}$ & $\begin{array}{c}(<6) \\
\text { LCC, LCB, LMC, } \\
\text { LBC, LBSM }\end{array}$ \\
\hline $\begin{array}{l}\text { Compressive Strength } \\
(\mathrm{MPa})\end{array}$ & $\begin{array}{c}\quad(<40) \\
\text { All limestones }\end{array}$ & $\begin{array}{l}(40-70) \\
\text { GRF }\end{array}$ & $\begin{array}{c}(70-130) \\
\text { GRD, GGG, GVV, } \\
\text { GJPT, GBSP, MBA }\end{array}$ & $(130-180)$ & $\begin{array}{c}(>180) \\
\text { GBC }\end{array}$ \\
\hline $\begin{array}{l}\text { Flexural Strength-3 } \\
\text { Point }(\mathrm{MPa})\end{array}$ & $\begin{array}{c}(<6) \\
\text { LMC, LBC, LBSM }\end{array}$ & $\begin{array}{c}(6-12) \\
\text { LBM, GBC, GRF, } \\
\text { GVV }\end{array}$ & $\begin{array}{c}(12-18) \\
\text { LCC, LCB, GRD, } \\
\text { GJPT }\end{array}$ & $\begin{array}{l}(18-22) \\
\text { GBSP }\end{array}$ & $\begin{array}{c}(>22) \\
\text { LCA, GGG }\end{array}$ \\
\hline $\begin{array}{l}\text { Impact Strength } \\
(\mathrm{m})\end{array}$ & $(<0.30)$ & $\begin{array}{c}(0.30-0.50) \\
\text { LCC, LCB, LBM, } \\
\text { LBC, LBM, LBSM }\end{array}$ & $\begin{array}{c}(0.50-0.70) \\
\text { LCA, GBC, GRF, } \\
\text { GRD, GGG, GVV, } \\
\text { GJPT }\end{array}$ & $\begin{array}{r}(0.70-0.95) \\
\text { GBSP, MBA }\end{array}$ & $(>0.95)$ \\
\hline $\begin{array}{c}\text { Wear } \\
\text { Resistance-Amsler } \\
(\mathrm{mm})\end{array}$ & $\begin{array}{c}(>6.0) \\
\text { LMC, LBC, LBM, } \\
\text { LBSM }\end{array}$ & $\begin{array}{l}(3.0-6.0) \\
\text { LCC }\end{array}$ & $\begin{array}{c}(1.5-3.0) \\
\text { LCA, LCB }\end{array}$ & $\begin{array}{c}(0.7-1.5) \\
\text { GRF, GRD, GVV, } \\
\text { GJPT }\end{array}$ & $\begin{array}{c}(<0.7) \\
\text { GBC, } \text { GGG, GBSP, } \\
\text { MBA }\end{array}$ \\
\hline
\end{tabular}

In general, granites have a microstructure composed of crystalline grains (quartz and mica) immersed in a feldspar matrix (see Figure 7), which gives, in addition to low porosity, a structure of grains and matrix interrelated with each other by strong primary connections. Among the granites, the GJPT sample was the one with the lowest compressive strength, probably due to the presence of micro-cracks as a result of its high thermal expansion coefficient $\left(11 \times 10^{-6}{ }^{\circ} \mathrm{C}^{-1}\right)$.

The limestones presented laminar characteristics and porosity between $6.7 \%$ and $13.7 \%$. The LCA sample showed promising results in strength compression and flexural strength—(30.2 \pm 4.8$) \mathrm{MPa}$ and $(24.7 \pm 2.3) \mathrm{MPa}$, respectively-compared to other limestones. This behavior is also directly related to the low porosity $(1.88 \% \pm 0.10 \%)$ presented by this sample $[69,70]$, which was the smallest among the studied limestones. The compressive strength of the limestones in this study varies between 16.5 and $34.3 \mathrm{MPa}$. LMC was the sample that showed the lowest CS value, with $(16.5 \pm 6.5) \mathrm{MPa}$, while LBM and LBSM exhibited the highest CS values, with (34.3 \pm 3.0$) \mathrm{MPa}$ and $(34.1 \pm 3.9) \mathrm{MPa}$, respectively. These values are similar to those found in studies by [51,52]. Granites have compressive strength values between 95.2 and 221.6 MPa. These values are within the range observed in commercial granites (CS varies between 60 and $292 \mathrm{MPa}$ ) [71]. Considering ASTM C170 and ASTM C99 [33,34], all limestones showed compressive and flexion strength values above the limit established for limestone with average density ( $\mathrm{CS} \geq 28 \mathrm{MPa}$ and FS $\geq 3.4 \mathrm{MPa}$ ). Regarding granites, only GBC (CS $=211.6 \mathrm{MPa}$ ) reached the expected value of compressive strength $(\mathrm{CS} \geq 130 \mathrm{MPa})$; however, for flexural strength, all samples reached the value of $\mathrm{FS} \geq 10.34 \mathrm{MPa}$, except GRF (FS = 9.8 MPa).

The impact strength value obtained for granites ranges between $0.53 \mathrm{~m}$ and $0.75 \mathrm{~m}$. As seen in Figure 7, the granite microstructure is formed by a glassy matrix of feldspar with quartz crystals. However, it is common for these granite microstructures to present microcracks around quartz crystals and small cracks resulting from differences in the coefficients of thermal expansion between the glass and crystalline phases. Thus, the impact strength is compromised, as the microstructure cannot absorb the impact's energy and 
the cracks formed end up spreading quickly. In limestones, the high porosity facilitates crack formation since the pores act as stress concentrators. However, these pores also act as barriers to the spread of cracks; the character of these laminar materials provides a series of plans for propagating the crack, which consumes the impact energy and minimizes damage to the material as a whole.

Resistance to abrasion wear is closely related to factors such as mineral hardness, weathering degree, and porosity. As the porosity increases, the functional area to withstand abrasive stress is smaller. Among the limestones, the LCA sample obtained the lowest porosity $(1.88 \%)$ and consequently the best abrasion resistance $(1.09 \mathrm{~mm})$. For granites, GBSP $(\mathrm{AP}=0.30 \%)$ was the one with the highest abrasion resistance $(0.11 \mathrm{~mm})$. The ASTM standard does not define values for Amsler wear in limestones, granites, and marbles. According to the NBR 15.844 standard [72], the maximum wear limit for a $1000 \mathrm{~m}$ course must be $\leq 1.0 \mathrm{~mm}$ for the natural stone to be considered good quality. In all limestones, wear was greater than $1 \mathrm{~mm}$. Their application should be avoided on floors, especially those intended for high traffic of people or heavy equipment. All granite and marble had values below the minimum limit established by the aforementioned standard; thus, these stones can be used on floors in areas with heavy traffic. The best performance was observed for GBC $(0.51 \mathrm{~mm})$, GGG $(0.48 \mathrm{~mm})$, and GBSP $(0.43 \mathrm{~mm})$, as these can maintain the polished surface layer over time, even when subject to high friction loads.

\subsection{Resistance to Chemical Attack}

The analysis of resistance to chemical attack is essential since several substances can compromise the useful life of the parts. In general, the limestone samples suffered the greatest changes in color and texture after exposure to chemical reagents. This behavior is possibly related to the high porosity values $(1.88-13.74 \%)$ compared to granites and marbles. The laminar structure also favors the infiltration of substances that affect mechanical and aesthetic aspects. In addition, carbonates (the main constituents of limestones) are sensitive to attack by acidic solutions [73].

The magnitude of the acid attack varied significantly according to the sample and the reagent used. Citric and hydrochloric acids were the reagents that most affected the surface of limestones and granites. Figures 8 and 9 show the limestone and granite sample images before and after exposure to citric acid $\left(\mathrm{C}_{6} \mathrm{H}_{8} \mathrm{O}_{7}\right)$ and hydrochloric acid $(\mathrm{HCl})$. Feldspars are sensitive to hydrochloric acid, which explains the more pronounced changes observed in granites when exposed to this acid. Table 8 shows the brightness values measured in the standard samples (without acid attack) and the samples exposed to the reagents. It is noted that the limestones showed an initial brightness significantly lower than that of granites; this was expected due to the high porosity of limestone.

When limestones and granites were exposed to ammonium chloride, most samples showed a loss of brightness of $5 \%$ to $20 \%$. No significant change was observed in the color or occurrence of mineral wear (corrosion). In marble, this loss of shine was more significant, around $27 \%$. However, the LMC and LBSM samples exhibited a $100 \%$ loss in brightness when exposed to all reagents, except for potassium hydroxide. This is probably related to the high content of $(\mathrm{CaO})$ presented by these samples (see Table 3). Sodium hypochlorite, which simulates bleaches and disinfectants, caused a loss of brightness in the limestones between $13 \%$ and $40 \%$. In granites, sodium hypochlorite caused a low loss of gloss (between $2 \%$ to $7 \%$ ), and no changes in color or surface corrosion were observed.

On the other hand, the marble showed slight corrosion and a loss of $3 \%$ in the gloss, which was not enough to modify its color. Citric acid caused deterioration in all limestones, in some granites (GRF, GGG, GVV, and GJPT), and in marble. The GBC, GRD, and GBSP samples showed no change in color, and the loss of brightness was in the range of $5 \%$ to $7 \%$. Except for GBC and GRD samples, all-natural stones showed corrosion when exposed to hydrochloric acid; however, no color changes were observed. On the other hand, potassium hydroxide did not cause a color change in the pieces, reducing the brightness by less than $10 \%$ for granites. 
Figure 10 presents the qualitative analysis of mass losses of the natural stones after exposure to chemical agents. All granites did not show mass loss when exposed to $\mathrm{NH}_{4} \mathrm{Cl}$ and $\mathrm{NaClO}$. The same was not observed for the limestone LMC, LCB, and LCC samples, which were the most affected for these reagents. $\mathrm{HCl}$ and $\mathrm{KOH}$ most frequently caused a mass loss in the samples, proving that these severely attack natural stones.

The mass losses resulting from exposure to $\mathrm{KOH}$ confirm that granites and limestones are attacked by this alkalizing agent, despite the small change in brightness produced by $\mathrm{KOH}$ in granites. Generally, alkalis attack silicates present in granite stones, which justifies their action on granites and the loss of mass observed. The mass loss of limestones and marble observed after exposure to $\mathrm{KOH}$ is probably related to an alkali-carbonate reaction, where alkalis, such as $\mathrm{Na}$ and $\mathrm{K}$, under certain $\mathrm{pH}$ conditions, attack carbonates forming hydroxides, which recrystallize, causing tensions and material damage (including loss of mass) [73]. This reaction occurs more intensely in dolomites or dolomitic limestones.

Table 8. Loss of brightness of samples after exposure to chemical reagents.

\begin{tabular}{|c|c|c|c|c|c|c|c|c|c|c|c|c|c|c|c|}
\hline \multirow{3}{*}{ Samples } & \multicolumn{3}{|c|}{$\mathrm{NH}_{4} \mathrm{Cl}$} & \multicolumn{3}{|c|}{$\mathrm{NaClO}$} & \multicolumn{3}{|c|}{$\mathrm{C}_{6} \mathrm{H}_{8} \mathrm{O}_{7}$} & \multicolumn{3}{|c|}{$\mathrm{HCl}$} & \multicolumn{3}{|c|}{ КОН } \\
\hline & \multicolumn{2}{|c|}{$\begin{array}{l}\text { Brightness } \\
\text { (GU) }\end{array}$} & \multirow{2}{*}{$\begin{array}{c}\text { Loss of } \\
\text { Brightness } \\
(\%)\end{array}$} & \multicolumn{2}{|c|}{$\begin{array}{l}\text { Brightness } \\
\text { (GU) }\end{array}$} & \multirow{2}{*}{$\begin{array}{c}\text { Loss of } \\
\text { Brightness } \\
(\%)\end{array}$} & \multicolumn{2}{|c|}{$\begin{array}{l}\text { Brightness } \\
\text { (GU) }\end{array}$} & \multirow{2}{*}{$\begin{array}{c}\text { Loss of } \\
\text { Brightness } \\
(\%)\end{array}$} & \multicolumn{2}{|c|}{$\begin{array}{l}\text { Brightness } \\
\text { (GU) }\end{array}$} & \multirow{2}{*}{$\begin{array}{c}\text { Loss of } \\
\text { Brightness } \\
(\%)\end{array}$} & \multicolumn{2}{|c|}{$\begin{array}{l}\text { Brightness } \\
\text { (GU) }\end{array}$} & \multirow{2}{*}{$\begin{array}{c}\text { Loss of } \\
\text { Brightness } \\
(\%)\end{array}$} \\
\hline & $I^{*}$ & $F^{*}$ & & $I^{*}$ & $F^{*}$ & & $I^{*}$ & $\mathbf{F}^{*}$ & & $I^{*}$ & $\mathbf{F}^{*}$ & & $I^{*}$ & $F^{*}$ & \\
\hline LCC & 5 & 4 & 20.0 & 3 & 2 & 33.3 & 3 & 0 & 100 & 3 & 1 & 66.7 & 3 & 2 & 33.3 \\
\hline LCA & 6 & 5 & 16.7 & 5 & 3 & 40.0 & 5 & 0 & 100 & 4 & 0 & 100 & 4 & 2 & 50 \\
\hline $\mathrm{LCB}$ & 34 & 30 & 11.8 & 30 & 26 & 13.3 & 29 & 0 & 100 & 30 & 0 & 100 & 34 & 31 & 8.8 \\
\hline LMC & 1 & 1 & 100 & 3 & 2 & 33.3 & 2 & 0 & 100 & 2 & 0 & 100 & 2 & 2 & 0 \\
\hline LBC & 6 & 5 & 16.7 & 7 & 6 & 14.3 & 7 & 0 & 100 & 8 & 0 & 100 & 6 & 5 & 16.7 \\
\hline LBM & 2 & 1 & 50 & 2 & 1 & 50 & 2 & 0 & 100 & 2 & 0 & 100 & 1 & 1 & 0 \\
\hline LBSM & 1 & 1 & 100 & 1 & 1 & 100 & 1 & 0 & 100 & 1 & 0 & 100 & 1 & 1 & 0 \\
\hline GBC & 80 & 75 & 6.3 & 78 & 73 & 6.4 & 78 & 74 & 5.1 & 74 & 69 & 6.8 & 76 & 73 & 3.9 \\
\hline GRF & 82 & 67 & 18.3 & 80 & 77 & 3.8 & 80 & 65 & 18.8 & 79 & 65 & 17.7 & 78 & 76 & 2.6 \\
\hline GRD & 79 & 64 & 19.0 & 76 & 71 & 6.6 & 78 & 73 & 6.4 & 78 & 73 & 6.4 & 74 & 70 & 5.4 \\
\hline GGG & 77 & 64 & 3.9 & 78 & 76 & 2.6 & 74 & 58 & 21.6 & 75 & 56 & 25.3 & 67 & 63 & 6.0 \\
\hline GVV & 81 & 76 & 6.2 & 83 & 79 & 4.8 & 63 & 40 & 36.5 & 77 & 48 & 37.7 & 77 & 72 & 6.5 \\
\hline GJPT & 84 & 81 & 3.6 & 80 & 76 & 5.0 & 78 & 32 & 59.0 & 80 & 63 & 21.3 & 81 & 78 & 3.7 \\
\hline GBSP & 78 & 70 & 10.3 & 76 & 73 & 3.9 & 74 & 69 & 6.8 & 70 & 67 & 4.3 & 77 & 74 & 3.9 \\
\hline MBA & 52 & 38 & 26.9 & 60 & 58 & 3.3 & 56 & 0 & 100 & 55 & 0 & 100 & 47 & 43 & 8.5 \\
\hline
\end{tabular}

$I^{*}$ : initial, $F^{*}$ : final, GU: gloss unit. 
LCC

LCA

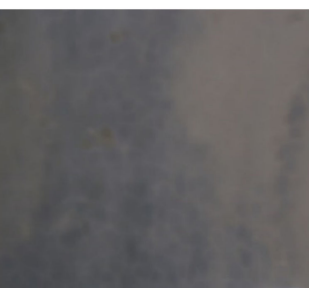

LCB

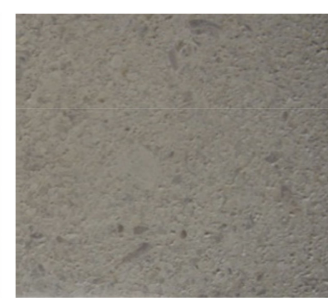

LMC

LBC
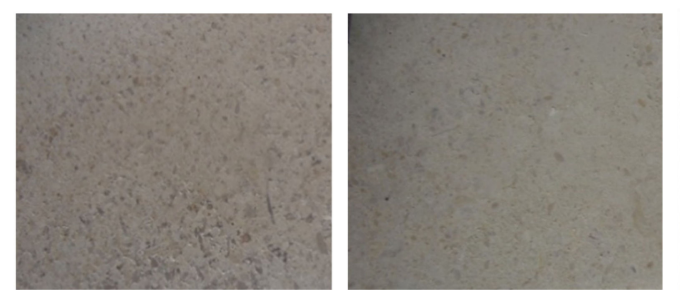

LBM

LBSM

Natural
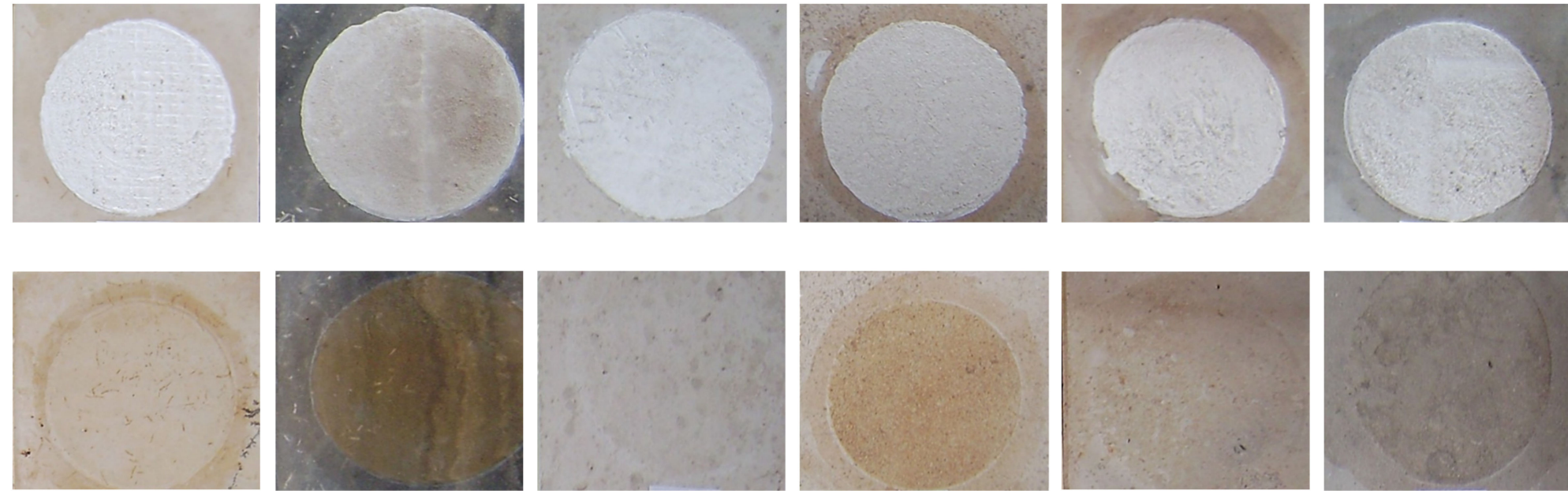

Figure 8. Samples of limestone stones before and after exposure to citric acid and hydrochloric acid.
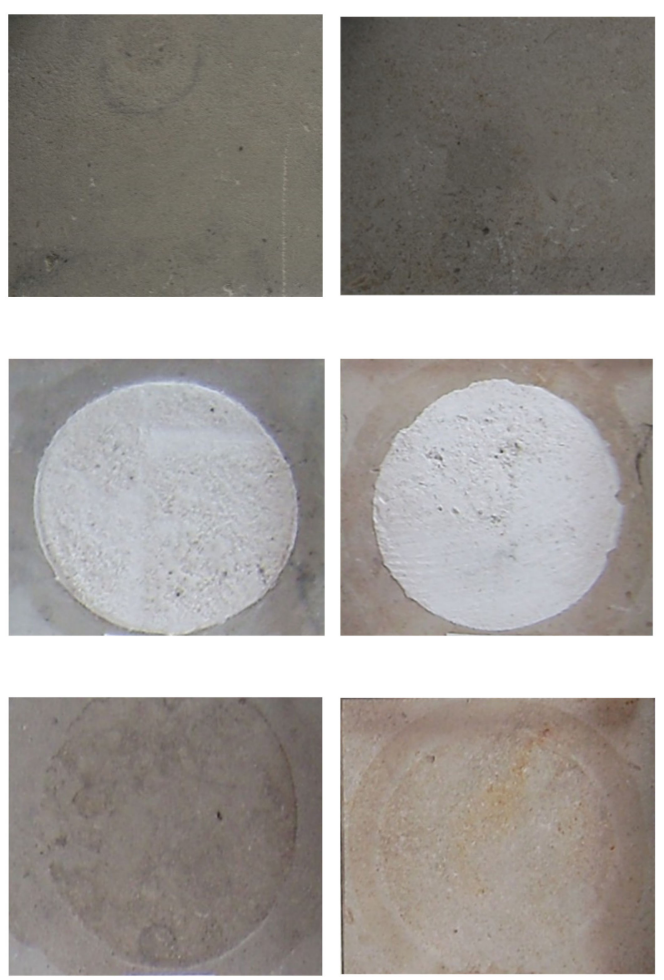


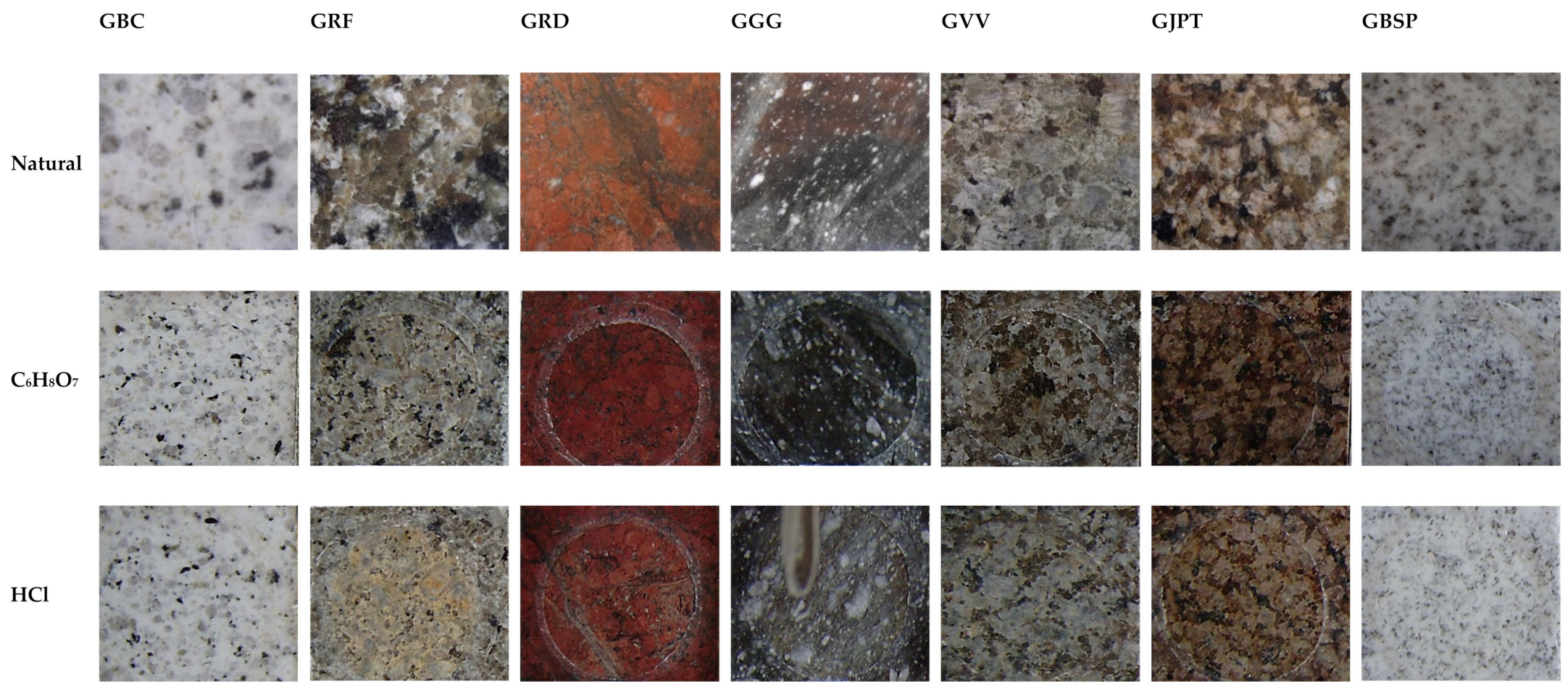

Figure 9. Samples of granite stones before and after exposure to citric acid and hydrochloric acid. 

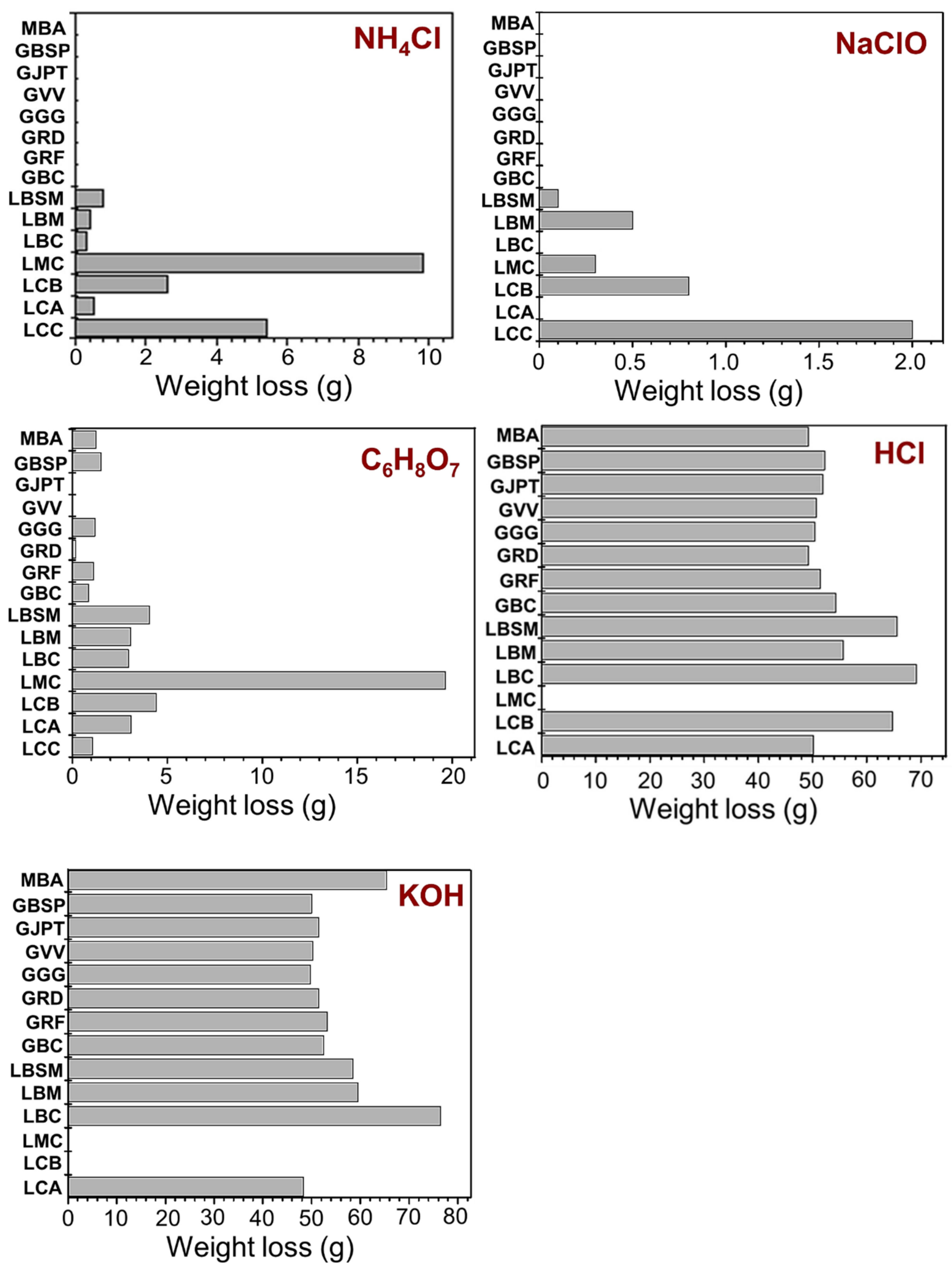

Figure 10. Loss of mass of the samples analyzed after exposure to chemical reagents.

\section{Conclusions}

The results obtained from chemical analyses, XDR, and DTA carried out on the selected samples indicated that the studied limestones can be classified according to the $\mathrm{MgO}$ content as calcitic limestone (LCC, LMC, and LBSM), magnesian limestone (LCA, LBC, and LCB), and dolomitic limestone (LBM). The investigated granites (GBC, GRF, 
GRD, GGG, GVV, GJPT, and GBSP) are constituted of feldspars (potassium feldspar and calcium-sodium feldspar) quartz, and mica. The GGG and GRD samples also showed a small amount of kaolinite, which may be present as an impurity or feldspar wear product. The reddish color presented by granites GRD and GJPT is probably associated with hematite inclusions in the feldspar matrix. The high MgO content detected in the MBA sample indicates that the investigated marble can be classified as dolomitic calcareous.

The analyzed limestones had high porosity $(1.88-13.74 \%)$ and suffered the greatest number of changes in color and texture after exposure to chemical reagents. After analyzing the physical properties, mechanical properties, and thermal expansion coefficient, it was possible to infer that the studied limestones can be used as natural stone tiles in low-traffic indoor environments without exposure to strong acidic or basic solutions. Among the studied limestones, LCA had the best mechanical and water absorption properties. On the other hand, the studied marbles and granites can be used as natural stone tiles for indoor and outdoor environments, even in high-traffic areas. They can also be used as tables, benches, and sinks as well as in other similar applications. However, care must be taken when exposing these stones to acids and alkalis, especially hydrochloric acid, since feldspar (the main constituent of granites) is sensitive to this acid. For application in outdoor conditions, GBC, GGG, and GBSP stones stand out for presenting the best results in water absorption and mechanical resistance.

Author Contributions: F.P.d.C., J.V.F. and L.R.L.d.M.: experimental data, data curation and formal analysis; G.d.A.N. and R.R.M.: conceptualization, funding acquisition and project administration; A.M.R.: formal analysis and Writing-review \& editing. All authors have read and agreed to the published version of the manuscript.

Funding: This research was funded by Coordenação de Aperfeiçoamento de Pessoal de Nível Superior (CAPES), grant numbers 88882.455332/2019-01 and 88882.455321/2019-01.

Data Availability Statement: Data available in a publicly accessible repository that does not issue DOIs since the main manuscript source was a Ph.D. thesis. That Ph.D. thesis is online at http: // dspace.sti.ufcg.edu.br:8080/jspui/handle/riufcg/7199. The author of the Ph.D. thesis and your supervisor are co-authors of the manuscript.

Acknowledgments: The authors would like to thank Limestone Ceará, Granus S/A, Mont Granitos S/A, Granistone S/A, Granus S/A, Imarf-Limestone and Granitos S/A, Multigran Ltd.A., Grandon $\mathrm{S} / \mathrm{A}$, and Geolux for providing the natural stones for this research and the reviewers for their comments and suggestions.

Conflicts of Interest: The authors declare no conflict of interest.

\section{References}

1. Pereira, D.; Marker, B. The Value of Original Natural Stone in the Context of Architectural Heritage. Geosciences 2016, 6, 13. [CrossRef]

2. Pereira, D.; Cooper, B.J. Building stone as a part of a World Heritage Site:'Piedra Pajarilla'Granite and the city of Salamanca, Spain. Geol. Soc. Lond. Spec. Publ. 2014, 391, 7-16. [CrossRef]

3. Bezerra, F.D. Rochas Ornamentais. Escritório Técnico Estud. Econômicos Nordeste ETENE 2018, 3, 1-22.

4. Ericsson, M. XXIX World Marble and Stones Report 2018 by Carlo Montani. Miner. Econ. 2019, 32, 255-256. [CrossRef]

5. Zulcão, R.; Calmon, J.L.; Rebello, T.A.; Vieira, D.R. Life cycle assessment of the ornamental stone processing waste use in cement-based building materials. Constr. Build. Mater. 2020, 257. [CrossRef]

6. $\quad$ Figueirêdo, J.M.R.d.; Costa, F.P.d.; Fernandes, J.V.; Rodrigues, A.M.; Neves, G.d.A.; Menezes, R.R.; Santana, L.N.d.L. Development of Scheelite Tailings-Based Ceramic Formulations with the Potential to Manufacture Porcelain Tiles, Semi-Stoneware and Stoneware. Materials 2020, 13, 5122. [CrossRef] [PubMed]

7. Fernandes, J.V.; Guedes, D.G.; Costa, F.P.d.; Rodrigues, A.M.; Neves, G.d.A.; Menezes, R.R.; Santana, L.N.d.L. Sustainable Ceramic Materials Manufactured from Ceramic Formulations Containing Quartzite and Scheelite Tailings. Sustainability 2020, $12,9417$. [CrossRef]

8. Pereira, M.A.M.; Silveira, L.M.; Nannini, F.; Neves, L.P.; Perini, A.P.; Santos, C.J.; Belinato, W.; Santos, W.S. Dosimetric evaluation of individuals to $238 \mathrm{U}$ series, $232 \mathrm{Th}$ series and $40 \mathrm{~K}$ radionuclides present in Brazilian ornamental rocks using computational simulation. Ecotoxicol. Environ. Saf. 2019, 173, 401-410. [CrossRef] [PubMed] 
9. Abd El-Ghafour, N.G.; Khalil, M.H.; Gharib, M.E.; Abd Latif, M.L. Mineralogical and radioactive properties of some Egyptian granitoid rocks and their suitability for ornamental stones. HBRC J. 2012, 8, 64-68. [CrossRef]

10. Montiel-Zafra, V.; Canadas-Quesada, F.; Campos-Suñol, M.J.; Vera-Candeas, P.; Ruiz-Reyes, N. Monitoring the internal quality of ornamental stone using impact-echo testing. Appl. Acoust. 2019, 155, 180-189. [CrossRef]

11. Carvalhão, M.; Dionísio, A. Evaluation of mechanical soft-abrasive blasting and chemical cleaning methods on alkyd-paint graffiti made on calcareous stones. J. Cult. Herit. 2015, 16, 579-590. [CrossRef]

12. Vázquez, P.; Luque, A.; Alonso, F.J; Grossi, C.M. Surface changes on crystalline stones due to salt crystallisation. Environ. Earth Sci. 2013, 69, 1237-1248. [CrossRef]

13. Benavente, D.; Martínez-Verdú, F.; Bernabé, A.; Viqueira, V.; Fort, R.; García Del Cura, M.A.; Illueca, C.; Ordóñez, S. Influence of Surface Roughness on Color Changes in Building Stones. Wiley Online Libr. 2003, 28, 343-351. [CrossRef]

14. Gadioli, M.C.B.; Ponciano, V.M.; Rocha Bessa, B.d.H.; Camargo, J.L.; Pizeta, P.P. Characterization of ornamental stones wastes for use in ceramic materials. Mater. Sci. Forum 2019, 958 MSF, 129-134. [CrossRef]

15. Khrissi, S.; Haddad, M.; Bejjit, L.; Lyazidi, S.A.; Amraoui, M.E.; Falguères, C. Preface: International Conference on Recent Trends in Physics (ICRTP 2016). IOP Conf. Ser. Mater. Sci. Eng. 2017, 186. [CrossRef]

16. Elkarmoty, M.; Colla, C.; Gabrielli, E.; Bonduà, S.; Bruno, R. A Combination of GPR Survey and Laboratory Rock Tests for Evaluating an Ornamental Stone Deposit in a Quarry Bench. Procedia Eng. 2017, 191, 999-1007. [CrossRef]

17. Abd, A.; Kahraman, E.A.S. Estimation of Durability Aspects of Al Masjid Al-Haram Marble, Makkah City, Saudi Arabia. Geotech. Geol. Eng. 2017, 35, 2763-2779. [CrossRef]

18. Sassoni, E.; Graziani, G.; Franzon, E.; Scherer, G.W. Conversion of calcium sulfate dihydrate into calcium phosphates as a route for conservation of gypsum stuccoes and sulfated marble. Constr. Build. Mater. 2018, 170, 290-301. [CrossRef]

19. Ruedrich, J.; Knell, C.; Enseleit, J.; Rieffel, Y.; Siegesmund, S. Stability assessment of marble statuaries of the Schlossbrücke (Berlin, Germany) based on rock strength measurements and ultrasonic wave velocities. Environ. Earth Sci. 2013, 69, 1451-1469. [CrossRef]

20. Karaca, Z.; Hacımustafaoğlu, R.; Gökçe, M. Grain properties, grain-boundary interactions and their effects on the characteristics of marbles used as building stones. Constr. Build. Mater. 2015, 93, 166-171. [CrossRef]

21. Vázquez, P.; Alonso, F.J.; Esbert, R.M.; Ordaz, J. Ornamental granites: Relationships between p-waves velocity, water capillary absorption and the crack network. Constr. Build. Mater. 2010, 24, 2536-2541. [CrossRef]

22. Saba, M.; Hernandez-Romero, L.N.; Lizarazo-Marriaga, J.; Quiñones-Bolaños, E.E. Petrographic of limestone cultural heritage as the basis of a methodology to rock replacement and masonry assessment: Cartagena de indias case of study. Case Stud. Constr. Mater. 2019, 11. [CrossRef]

23. Almada, B.S.; Melo, L.d.S.; Dutra, J.B.; Bubani, L.C.; Silva, G.J.B.; Santos, W.J.d.; Aguilar, M.T.P. Influence of the heterogeneity of waste from wet processing of ornamental stones on the performance of Portland cement composites. Constr. Build. Mater. 2020, 262, 120036. [CrossRef]

24. Bacarji, E.; Toledo Filho, R.D.; Koenders, E.A.B.; Figueiredo, E.P.; Lopes, J.L.M.P. Sustainability perspective of marble and granite residues as concrete fillers. Constr. Build. Mater. 2013, 45, 1-10. [CrossRef]

25. Souza, A.J.; Pinheiro, B.C.A.; Holanda, J.N.F. Processing of floor tiles bearing ornamental rock-cutting waste. J. Mater. Process. Technol. 2010, 210, 1898-1904. [CrossRef]

26. Rodrigues, R.; De Brito, J.; Sardinha, M. Mechanical properties of structural concrete containing very fine aggregates from marble cutting sludge. Constr. Build. Mater. 2015, 77, 349-356. [CrossRef]

27. Sousa, L.M.O.; Suárez del Río, L.M.; Calleja, L.; Ruiz de Argandoña, V.G.; Rodríguez Rey, A. Influence of microfractures and porosity on the physico-mechanical properties and weathering of ornamental granites. Eng. Geol. 2005, 77, 153-168. [CrossRef]

28. Castro, N.F.; Mansur, K.L.; Frascá, M.H.B.d.O.; Silva, R.E.C. A heritage stone of Rio de Janeiro (Brazil): The Facoidal gneiss. Episodes J. Int. Geosci. 2021. [CrossRef]

29. Castro, N.; Mansur, K.; Frascá, M.H. The augen gneiss of a bright and dark history. In Proceedings of the 21st EGU General Assembly, EGU2019, Vienna, Austria, 7-12 April 2019; 21, p. 1.

30. Morales Demarco, M.; Oyhantçabal, P.; Stein, K.J.; Siegesmund, S. Granitic dimensional stones in Uruguay: Evaluation and assessment of potential resources. Environ. Earth Sci. 2013, 69, 1397-1438. [CrossRef]

31. Pereira, D.; Blanco, J.A.; Peinado, M. Study on Serpentinites and the Consequence of the Misuse of Natural Stone in Buildings for Construction. J. Mater. Civ. Eng. 2013, 25, 1563-1567. [CrossRef]

32. ASTM. ASTM C97/C97M-Standard Test Methods for Absorption and Bulk Specific Gravity of Dimension Stone; ASTM International: West Conshohocken, PA, USA, 2015.

33. ASTM. ASTM C170/C170M—Standard Test Method for Compressive Strength of Dimension Stone; ASTM International: West Conshohocken, PA, USA, 2017.

34. ASTM. ASTM C99/C99M-Standard Test Method for Modulus of Rupture of Dimension Stone; ASTM International: West Conshohocken, PA, USA, 2018.

35. ASTM. ASTM C880/C880M-Standard Test Method for Flexural Strength of Dimension Stone; ASTM International: West Conshohocken, PA, USA, 2018.

36. ASTM. ASTM C241/C241M-Standard Test Method for Abrasion Resistance of Stone Subjected to Foot Traffic; ASTM International: West Conshohocken, PA, USA, 2015. 
37. International Standards Organization. Ceramic Tiles: Determination of Chemical Resistance, ISO 10545-1-Part 13; International Standards Organization: Geneva, Switzerland, 2016.

38. De Souza, F.; Bragança, S.R. Thermogravimetric analysis of limestones with different contents of MgO and microstructural characterization in oxy-combustion. Thermochim. Acta 2013, 561, 19-25. [CrossRef]

39. Jakhar, S.R.; Mathur, R. Dimensional Stones: Weathering Nature and Technical Properties. Int. J. Sci. Res. 2015, 5, 710-715. [CrossRef]

40. Urones, E.; Ramil, A.; Otero, C. Microstructural study of the origin of color in Rosa Porriño granite and laser cleaning effects. Appl. Phys. A 2011, 95-101. [CrossRef]

41. Sajid, M.; Coggan, J.; Arif, M.; Andersen, J.; Rollinson, G. Petrographic features as an effective indicator for the variation in strength of granites. Eng. Geol. 2016, 202, 44-54. [CrossRef]

42. Plevova, E.; Vaculikova, L.; Kozusnikova, A.; Ritz, M.; Simha Martynkova, G. Thermal expansion behaviour of granites. J. Therm. Anal. Calorim. 2016, 123, 1555-1561. [CrossRef]

43. Yusof, N.Q.A.M.; Zabidi, H. Correlation of mineralogical and textural characteristics with engineering properties of granitic rock from Hulu Langat, Selangor. Procedia Chem. 2016, 19, 975-980. [CrossRef]

44. Tuğrul, A.; Zarif, I.H. Correlation of mineralogical and textural characteristics with engineering properties of selected granitic rocks from Turkey. Eng. Geol. 1999, 51, 303-317. [CrossRef]

45. Jeong, G.Y. The dependence of localized crystallization of halloysite and kaolinite on primary minerals in the weathering profile of granite. Clays Clay Miner. 2000, 48, 196-203. [CrossRef]

46. Piller, W.E.; Egger, H.; Gross, M.; Harzhauser, M.; Hubmann, B.; Van Husen, D.; Krenmayr, H.-G.; Krystyn, L.; Lein, R.; Mandl, G.; et al. Die stratigraphische Tabelle von Österreich 2004 (sedimentäre Schichtfolgen). Osterr. Stratigr. Komm 2004, 9, 24-26.

47. Baud, P.; Exner, U.; Lommatzsch, M.; Reuschlé, T.; Wong, T.-F. Mechanical behavior, failure mode, and transport properties in a porous carbonate. J. Geophys. Res. Solid Earth 2017, 122, 7363-7387. [CrossRef]

48. Kourkoulis, S.K. Fracture and Failure of Natural Building Stones: Applications in the Restoration of Ancient Monuments; Springer Science \& Business Media: Berlin, Germany, 2006; ISBN 978-1-4020-5076-3.

49. Naeem, M.; BinSadiq, R.A.; Anwar, M.; Khalid, P. Mechanical properties and petrographic characteristics of Margala Hill limestone and Lockhart limestone of Rumli area, Islamabad Pakistan. Acta Geod. Geophys. 2014, 49, 441-454. [CrossRef]

50. ASTM. ASTM C568/C568M—Standard Specification for Limestone Dimension Stone; ASTM International: West Conshohocken, PA, USA, 2015.

51. Vigroux, M.; Eslami, J.; Beaucour, A.L.; Bourgès, A.; Noumowé, A. High temperature behaviour of various natural building stones. Constr. Build. Mater. 2021, 272, 121629. [CrossRef]

52. Eslami, J.; Walbert, C.; Beaucour, A.L.; Bourges, A.; Noumowe, A. Influence of physical and mechanical properties on the durability of limestone subjected to freeze-thaw cycles. Constr. Build. Mater. 2018, 162, 420-429. [CrossRef]

53. Buj, O.; López, P.L.; Gisbert, J. Caracterización del sistema poroso y de su influencia en el deterioro por cristalización de sales en calizas y dolomías explotadas en abanto (Zaragoza, España). Mater. Constr. 2010, 60, 99-114. [CrossRef]

54. Karaca, Z.; Öztank, N.; Gökçe, M.V.; Elçi, H. Effects of surface-finishing forms and cement-filling on porous dimension limestone deterioration in cold regions. Cold Reg. Sci. Technol. 2011, 68, 124-129. [CrossRef]

55. Pires, V.; Silva, Z.S.G.; Simão, J.A.R.; Galhano, C.; Amaral, P.M. “Bianco di Asiago” limestone pavement-Degradation and alteration study. Constr. Build. Mater. 2010, 24, 686-694. [CrossRef]

56. Fronteau, G.; Moreau, C.; Thomachot-Schneider, C.; Barbin, V. Variability of some Lutetian building stones from the Paris Basin, from characterisation to conservation. Eng. Geol. 2010, 115, 158-166. [CrossRef]

57. Török, Á. Surface strength and mineralogy of weathering crusts on limestone buildings in Budapest. Build. Environ. 2003, 38, 1185-1192. [CrossRef]

58. Cardell, C.; Benavente, D.; Rodríguez-Gordillo, J. Weathering of limestone building material by mixed sulfate solutions. Characterization of stone microstructure, reaction products and decay forms. Mater. Charact. 2008, 59, 1371-1385. [CrossRef]

59. Cnudde, V.; Cwirzen, A.; Masschaele, B.; Jacobs, P.J.S. Porosity and microstructure characterization of building stones and concretes. Eng. Geol. 2009, 103, 76-83. [CrossRef]

60. ASTM. ASTM C615/C615M—Standard Specification for Granite Dimension Stone; ASTM International: West Conshohocken, PA, USA, 2018.

61. Gunes Yilmaz, N.; Karaca, Z.; Goktan, R.M.; Akal, C. Relative brittleness characterization of some selected granitic building stones: Influence of mineral grain size. Constr. Build. Mater. 2009, 23, 370-375. [CrossRef]

62. Rivas, T.; Alvarez, E.; Mosquera, M.J.; Alejano, L.; Taboada, J. Crystallization modifiers applied in granite desalination: The role of the stone pore structure. Constr. Build. Mater. 2010, 24, 766-776. [CrossRef]

63. ISO. ISO 10545-3:1995 Ceramic Tiles-Part 3: Determination of Water Absorption, Apparent Porosity, Apparent Relative Density and Bulk Density; International Standards Organization: Geneva, Switzerland, 2014.

64. Harvey, R.D.; Frye, J.C. Thermal Expansion of Certain Illinois Limestones and Dolomites; State of Illinois Department of Registration and Education, Illinois State Geological Survey: Urbana, IL, USA, 1967; Volume 415.

65. Siegesmund, S.; Mosch, S.; Scheffzük, C.; Nikolayev, D.I. The bowing potential of granitic rocks: Rock fabrics, thermal properties and residual strain. Environ. Geol. 2008, 55, 1437-1448. [CrossRef] 
66. Weiss, T.; Siegesmund, S.; Kirchner, D.T.; Sippel, J. Insolation weathering and hygric dilatation: Two competitive factors in stone degradation. Environ. Geol. 2004, 46, 402-413. [CrossRef]

67. de Castro Lima, J.J.; Paraguassú, A.B. Linear thermal expansion of granitic rocks: Influence of apparent porosity, grain size and quartz content. Bull. Eng. Geol. Environ. 2004, 63, 215-220. [CrossRef]

68. Siegesmund, S.; Sousa, L.; Knell, C. Thermal expansion of granitoids. Environ. Earth Sci. 2018, 77, 41. [CrossRef]

69. Costa, F.P.d.; Morais, C.R.d.S.; Rodrigues, A.M. Sustainable glass-ceramic foams manufactured from waste glass bottles and bentonite. Ceram. Int. 2020, 46, 17957-17961. [CrossRef]

70. Costa, F.P.d.; Morais, C.R.d.S.; Pinto, H.C.; Rodrigues, A.M. Microstructure and physico-mechanical properties of Al2O3-doped sustainable glass-ceramic foams. Mater. Chem. Phys. 2020, 256, 123612. [CrossRef]

71. Siegesmund, S.; Dürrast, H. Physical and mechanical properties of rocks. In Stone in Architecture: Properties, Durability; Springer: Berlin/Heidelberg, Germany, 2011; pp. 97-225. ISBN 9783642144745.

72. NBR 15844. Rochas para Revestimento-Requisitos para granitos. Assoc. Bras. Normas Técnicas 2015, 1-2.

73. Fernandes, J.V.; Rodrigues, A.M.; Menezes, R.R.; Neves, G.d.A. Adsorption of anionic dye on the acid-functionalized bentonite. Materials 2020, 13, 3600. [CrossRef] 